Article

\title{
Geochemical Modelling of the Evolution of Caprock Sealing Capacity at the Shenhua CCS Demonstration Project
}

\author{
Guodong Yang ${ }^{1,2} \mathbb{D}$, Xin Ma ${ }^{3, *}$, Tao Feng ${ }^{1,2}$, Ying Yu ${ }^{4, *}$, Shuguo Yin ${ }^{1}$, Mian Huang ${ }^{1}$ and \\ Yongsheng Wang ${ }^{5}$ \\ 1 College of Resource and Environmental Engineering, Wuhan University of Science and Technology, \\ Wuhan 430081, China; guodongyang@wust.edu.cn (G.Y.); fengtaowhu@163.com (T.F.); \\ ysg199606@163.com (S.Y.); mianhuang323@163.com (M.H.) \\ 2 Hubei Key Laboratory for Efficient Utilization and Agglomeration of Metallurgic Mineral Resources, \\ Wuhan University of Science and Technology, Wuhan 430081, China \\ 3 Center for Hydrogeology and Environmental Geology Survey, CGS, Baoding 071051, China \\ 4 School of Environmental Studies, China University of Geosciences, Wuhan 430074, China \\ 5 China Shenhua Coal Liquefaction Co., Ltd. Ordos, Ordos 017209, China; wys202114@163.com \\ * Correspondence: maxin@mail.cgs.gov.cn (X.M.); yuying@cug.edu.cn (Y.Y.); \\ Tel.: +86-17717707602 (X.M.); +86-13554098727 (Y.Y.)
}

Received: 16 October 2020; Accepted: 10 November 2020; Published: 12 November 2020

\begin{abstract}
CO}_{2}$ geological storage is considered as an important measure to reduce anthropogenic $\mathrm{CO}_{2}$ emissions to the atmosphere for addressing climate change. The key prerequisite for long-term $\mathrm{CO}_{2}$ geological storage is the sealing capacity of caprock. This study investigates the evolution of sealing capacity of caprock induced by geochemical reactions among $\mathrm{CO}_{2}$, water and caprock using TOUGHREACT code based on the Heshanggou Formation mudstone at the Shenhua Carbon Capture and Storage (CCS) demonstration site of China. The results show that the self-sealing phenomenon occurs in the lower part of the caprock dominated by the precipitation of dawsonite, magnesite, siderite, Ca-smectite and illite. While the self-dissolution occurs in the upper part of caprock mainly due to the dissolution of kaolinite, K-feldspar, chlorite and Ca-smectite. Sensitivity analyses indicate that the precipitation of dawsonite, magnesite, siderite is highly advantageous leading to self-sealing of caprock, with albite and chlorite dissolution providing $\mathrm{Na}^{+}, \mathrm{Mg}^{2+}$ and $\mathrm{Fe}^{2+}$. The dissolution of K-feldspar dominates illite precipitation by providing required $\mathrm{K}^{+}$, and albite affects Ca-smectite precipitation. The self-sealing and self-dissolution of caprock are enhanced significantly with increasing temperature, while the effect of salinity on caprock sealing capacity is negligible perhaps due to the low salinity level of formation water.
\end{abstract}

Keywords: carbon capture and storage (CCS); $\mathrm{CO}_{2}$ geological storage; $\mathrm{CO}_{2}$-water-rock interaction; sealing capacity of caprock; self-sealing; self-dissolution; geochemical modelling; Shenhua CCS demonstration project

\section{Introduction}

The increasing concentration of anthropogenic $\mathrm{CO}_{2}$ in the atmosphere has caused significant global climate change. $\mathrm{CO}_{2}$ emission reduction has attracted extensive attention from the international community, especially the scientific community [1]. Among the existing emission reduction ways, carbon capture and storage (CCS) in geological formations such as deep saline aquifers, oil and gas reservoirs, and un-minable coal beds, is considered to be the most promising options for lowering anthropogenic emissions of $\mathrm{CO}_{2}$ to the atmosphere on a large scale [2,3]. Recently, CCS technologies 
have been extended to CCUS (carbon capture, utilization and storage) technologies, which can reduce $\mathrm{CO}_{2}$ emissions and obtain economic benefits at the same time [4-6]. A series of CCS or CCUS operations and demonstration projects have been launched around the world, including the Sleipner site in the Norwegian part of the North Sea [7], the CO2CRC Otway project in Victoria, Australia [8], the In Salah operation in Algeria [9], the Weyburn project in Canada [10]; Cranfield project in Mississippi, USA [11]; and the Shenhua CCS demonstration project in the Ordos Basin, China [12].

For the implementation of a large-scale CCS/CCUS project, the primary concern is the sealing capacity of caprock overlying the $\mathrm{CO}_{2}$ storage reservoir, which improves the long-term safety of $\mathrm{CO}_{2}$ geological storage [13]. The injected $\mathrm{CO}_{2}$ can accumulate with time under the caprock due to its low permeability and high capillary entry pressure [14-16]. However, $\mathrm{CO}_{2}$ may infiltrate into the initially water-saturated caprock when buoyancy pressure is higher than the capillary entry pressure. The intruded $\mathrm{CO}_{2}$ dissolves into the formation fluid making an acidic medium which reacts with the caprock matrix, leading to mineral dissolution and precipitation and associated self-sealing and self-dissolution of caprock [17-20]. Such changes can significantly influence the sealing capacity of caprock and eventually affect the safe and long-term storage of $\mathrm{CO}_{2}$.

It is crucial to understand the mechanism of the geochemical interactions among caprock minerals, water and $\mathrm{CO}_{2}$ to characterize the evolution of caprock sealing capacity for long-term $\mathrm{CO}_{2}$ storage. Many experimental studies have been performed to investigate the effect of geochemical reactions on mineral alterations and caprock permeability [21-26]. Batch and flow-through experiments have reported acidified $\mathrm{CO}_{2}$-rich brines react with the caprock minerals resulting in the dissolution of primary minerals and the precipitation of secondary minerals, which are affected by mineral compositions and reservoir conditions. Alemu et al. [25] compared carbonate- and clay-rich shale batch reactions with $\mathrm{CO}_{2}$ and water. They found that carbonate-rich shale is highly reactive, which may lead to porosity increase. According to [17], the geochemical reaction rates are accelerated whereas the mineral reaction mechanism is changed due to high temperature. These studies have determined significant mineral alterations and changes in pore structure and porosity/permeability of caprock due to the dissolution and precipitation of carbonate and clay minerals $[17,21,25,27]$.

Geochemical reactions can occur for hundreds to thousands of years and may make a significant contribution to alterations in permeability and thus the sealing capacity of caprock $[13,28]$. Consequently, several numerical models of geochemical reactions have been recently conducted to evaluate the sealing capacity of caprock [7,29-34]. Tian et al. [29] investigated the impact of heterogeneous mineralogical composition on the sealing capacity of caprock for a $\mathrm{CO}_{2}$ geological storage site. They found that the spatial variation in mineral composition slightly enhanced the sealing capacity of the caprock. The work of Xiao et al. [30] suggested increased caprock sealing efficiency resulting from maximum porosity decreases $\sim 25 \%$ at the reservoir-caprock interface due to mineral precipitation in the Morrow Shale under typical $\mathrm{CO}_{2}$ enhanced oil recovery $\left(\mathrm{CO}_{2}\right.$-EOR) conditions, by considering the influence of hydrological and mineralogical heterogeneity. Most of these geochemical modelling studies report the dissolution of carbonate and feldspar minerals, along with secondary carbonate and clay minerals precipitation due to $\mathrm{CO}_{2}$ charged brine reacting with caprock minerals. These geochemical processes could affect solid volume, and hydrodynamic and mechanical properties of the caprocks, which have the potential to affect porosity and permeability changes, thereby enhancing or weakening the sealing capacity of caprock [31,32,35]. Gherardi et al. [31] conducted reactive transport simulations in the caprock of a depleted gas reservoir for $\mathrm{CO}_{2}$ storage using TOUGHREACT code (Version 1.2, Lawrence Berkeley National Laboratory (LBNL), Berkeley, CA, USA) [36]. They found that when free $\mathrm{CO}_{2}$ enters into the caprock through existing fractures or high permeability zones, self-dissolution alteration occurs due to the dominant geochemical reaction of significant calcite and dolomite dissolution in caprock. By contrast, some calcite precipitation is predicted leading to further sealing of the storage reservoir when fluid-rock interactions occur under fully liquid-saturated conditions and a diffusion-controlled regime. Similarly, Tian et al. [32] evaluate the effects of generated random heterogeneous permeability 
on the migration of $\mathrm{CO}_{2}$ within the caprock, the alteration of minerals and the associated evolution of the caprock sealing efficiency.

The above studies suggest that the geochemical interactions among $\mathrm{CO}_{2}$, water and caprock cause minerals alteration in caprock. The dominant mineral dissolution/precipitation reaction(s) may lead to porosity/permeability reduction or enhancement, and thus potentially contribute significantly to the evolution of sealing capacity of caprock, which can affect long-term safety of $\mathrm{CO}_{2}$ storage. However, a number of factors, namely the caprock mineralogy, water chemistry, and formation properties (e.g., temperature, pressure, salinity and thickness) differ from site to site, which might accelerate or retard different geochemical reactions, thereby influencing the sealing capacity of caprock $[16,20,31,34]$. Therefore, the geochemical reactions which occur in caprock are site-specific and need to be investigated case by case. Moreover, due to the fact that $\mathrm{CO}_{2}$-water-caprock geochemical processes are very slow under the actual storage conditions, laboratory experiments have certain limitations (e.g., short laboratory time scale and the increase of reactive surface areas). It is imperative to carry out numerical simulation of the geochemical reactions among $\mathrm{CO}_{2}$, water and caprock to evaluate the long term caprock sealing capacity based on the actual site characteristics.

The main aim of this study was to investigate the evolution of seal capacity of mudstone caprock induced by geochemical reactions during long-term $\mathrm{CO}_{2}$ storage. A vertical one-dimensional model was employed to represent the reservoir-caprock system based on the seismic, well testing and logging data of Heshanggou Formation (regional seals) and Liujiagou Formation (the upmost reservoir) at the Shenhua CCS demonstration site of China. Reactive transport modelling was conducted to analyze mineral dissolution and precipitation mechanisms and their impact on the changes in caprock sealing capacity using TOUGHREACT. Moreover, sensitivity analyses of key mineral composition, formation temperature and salinity variables were made. The results could have a novel scientific contribution for evaluating the caprock sealing and $\mathrm{CO}_{2}$ storage potential in the large-scale implementation of CCS/CCUS projects from the perspective of geochemistry.

\section{Site Characteristics of Shenhua CCS Demonstration Project}

The Shenhua CCS project lies in the Chenjiacun village of Wulam Len town, EjinHoro county, about $40 \mathrm{~km}$ southeast of the Ordos City, Inner Mongolia and $17 \mathrm{~km}$ northwest to the Shenhua Coal Liquefaction Co., Ltd- $\mathrm{CO}_{2}$ source [12]. It is tectonically located on the east section of the Yimeng Uplift of the northern part of the Ordos Basin (Figure 1). The Ordos Basin, covering an area of $250,000 \mathrm{~km}^{2}$, is the second-largest sedimentary basin and an important energy base in China. The $\mathrm{CO}_{2}$ storage capacity of deep saline aquifers in the Ordos Basin is estimated to be more than 10 billion tons $[12,37]$. The injection operation is structured so that $\mathrm{CO}_{2}$ is injected into multiple layers from the Liujiagou Formation through to the Majiagou Formation, with Heshanggou Formation to Jurassic strata (mudstone, silty mudstone and shale) as the regional seals (Figure 1).

The bottom of the Heshanggou Formation is mainly composed of mudstone, which is the first barrier to prevent $\mathrm{CO}_{2}$ escape. The average porosity and permeability of this section are $2.99 \%$ and $0.25 \mathrm{mD}$, respectively, which is a low porosity and low permeability formation. The top of the Liujiagou Formation is composed of light brownish red fine sandstone with brownish red mudstone, whose sandstone is mainly lithic arkose and feldspathic litharenite. The average porosity and permeability of the top Liujiagou Formation is $11.40 \%$ and $4.5 \mathrm{mD}$, respectively, which defines it as a low permeability formation [38]. 


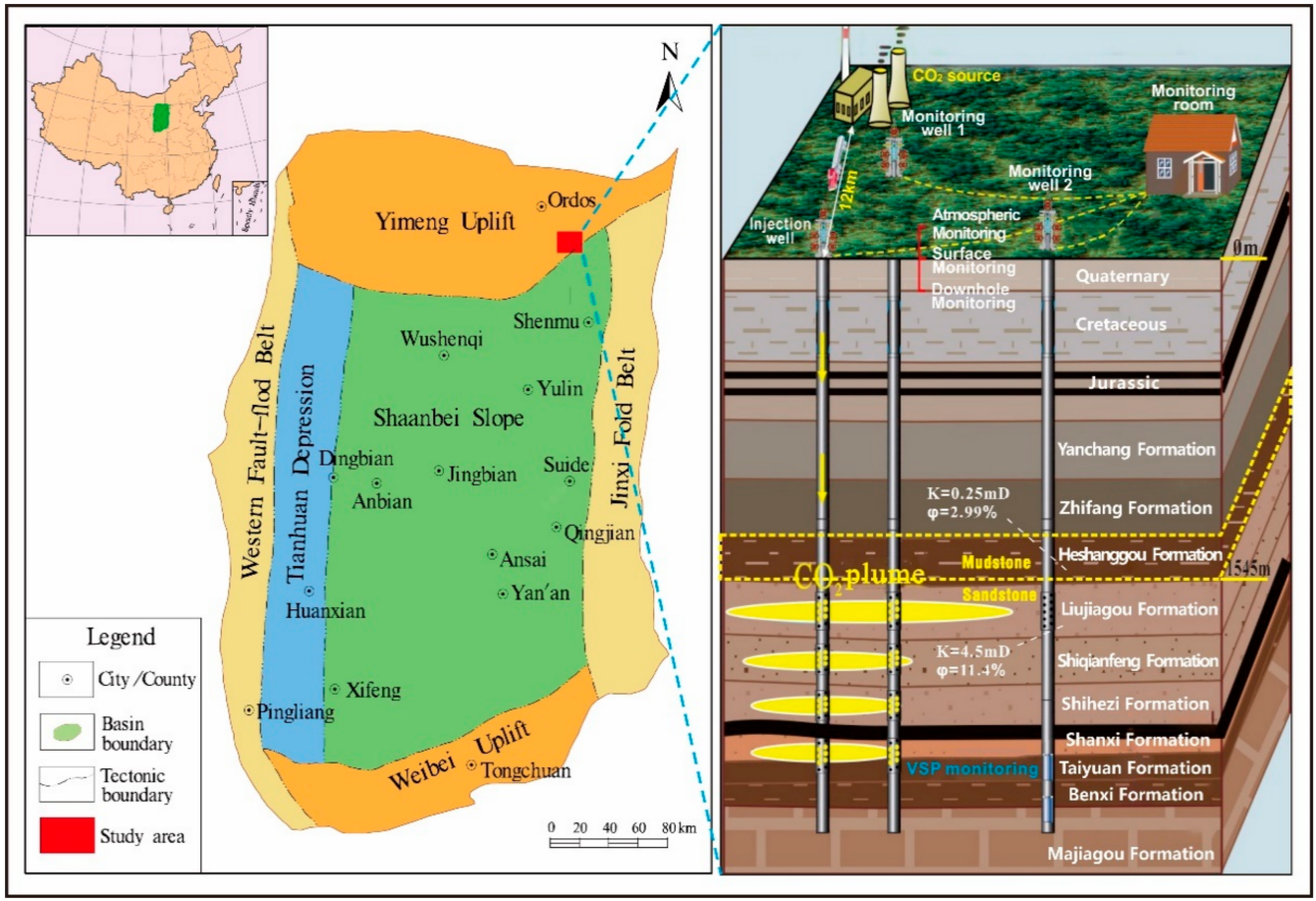

Figure 1. Location and stratigraphic structure of Shenhua CCS demonstration area in the Ordos Basin, China (Modified from $[37,38]$ ).

\section{Modelling Approach}

\subsection{Numerical Tool}

All simulations are conducted using the TOUGHREACT/ECO2N code $[36,39]$. The numerical method for fluid flow and chemical transport simulation is based on the integral finite difference (IFD) method for space discretization. The resulting concentrations obtained from the transport simulations are then substituted into a chemical reaction model. The system of chemical reaction equations is solved on a grid-block basis by Newton-Raphson iteration. Thermodynamic data of aqueous species and minerals used in the simulations are taken from the EQ3/6 database [40], which have been derived from SUPCRT92. For local equilibrium constants and kinetic rates used in TOUGHREACT refer to [39]. Full details on the simulator are given in Xu et al. [36,39].

Porosity and permeability are the key parameters in CCS that can affect the $\mathrm{CO}_{2}$ injectivity and caprock sealing. The variation of porosity is directly tied to the volume changes as a result of mineral alteration, which is calculated by:

$$
\phi=1-\sum_{b=1}^{a b} f r_{b}-f r_{u}
$$

where $a b$ is the number of minerals; $f r_{b}$ is the volume fraction of mineral $b$ in the rock $\left(V_{\text {mineral }} / V_{\text {medium }}\right.$, including porosity); and $f r_{u}$ is the volume fraction of nonreactive rock.

Permeability changes are calculated from changes in porosity using ratios of permeabilities as per the Kozeny-Carman grain model [39], as follows:

$$
k=k_{i} \frac{\left(1-\phi_{i}\right)^{2}}{(1-\phi)^{2}}\left(\frac{\phi}{\phi_{i}}\right)^{3}
$$

where $k_{i}$ is the initial permeability; $\phi$ and $\phi_{i}$ are current and initial porosity, respectively. 


\subsection{Model Description}

According to the underground conditions of the bottom Heshanggou Formation at depths of 1495-1545 m and the top Liujiagou Formation at depths of 1545-1555 m at the Shenhua CCS demonstration site, a vertical one-dimensional (1D) model representing $50 \mathrm{~m}$ thick caprock and $10 \mathrm{~m}$ thick reservoir is employed (Figure 2), which was developed in our previous studies [38,41]. The $60 \mathrm{~m}$ column is divided into a total of 52 layers in the vertical direction, with caprock of 51 layers of equal thickness and reservoir of 1 layer. The grid cells of the other two directions are $1 \mathrm{~m}$. An infinite volume element of $10^{25} \mathrm{~m}^{3}$ is set on the uppermost grid of the caprock, representing constant pressure boundary in the simulation that hydrogeological parameters of the caprock are stable. The volume of the reservoir is $10 \mathrm{~m}^{3}$. This setting can not only reflect the evolution of reservoir pressure and $\mathrm{CO}_{2}$ gas saturation after shutting down the injection well, but also consider the effect of geochemical reactions on caprocks.

The formation pressure at a depth of $1550 \mathrm{~m}$ is estimated approximately at $15.0 \mathrm{MPa}$ based on the well drilling measurements of Zhongshenjian 2\#. For the convenience of calculation, the initial pressure for the model is set to be at static hydraulic pressure state. Then the hydrostatic pressure distribution in the caprock is set by hydrostatic equilibrium, with $14.5 \mathrm{MPa}$ to $15 \mathrm{MPa}$ from the top to the bottom of the caprock. After $\mathrm{CO}_{2}$ injection, the pressure gradient of reservoir fluctuates between $0.32 \mathrm{MPa}$ and $0.45 \mathrm{MPa}$. Therefore, the pressure of the reservoir is set to $15.5 \mathrm{MPa}$, exceeding the hydrostatic pressure of the caprock bottom by $0.5 \mathrm{MPa}$. The average temperature of $53^{\circ} \mathrm{C}$ is applied to the whole model. As key parameters that dominate the $\mathrm{CO}_{2}$ migration and storage, the vertical permeabilities of the caprock and reservoir are set to $2.5 \times 10^{-17} \mathrm{~m}^{2}$ and $4.5 \times 10^{-16} \mathrm{~m}^{2}$, respectively, which are taken as $1 / 10$ of the horizontal permeabilities [31]. The caprock is initially water-saturated, whereas the reservoir is assumed to be in two-phase conditions with $\mathrm{CO}_{2}$ saturation of 0.8 [31,38]. Details in hydrogeological parameters used in the model are listed in Table 1.

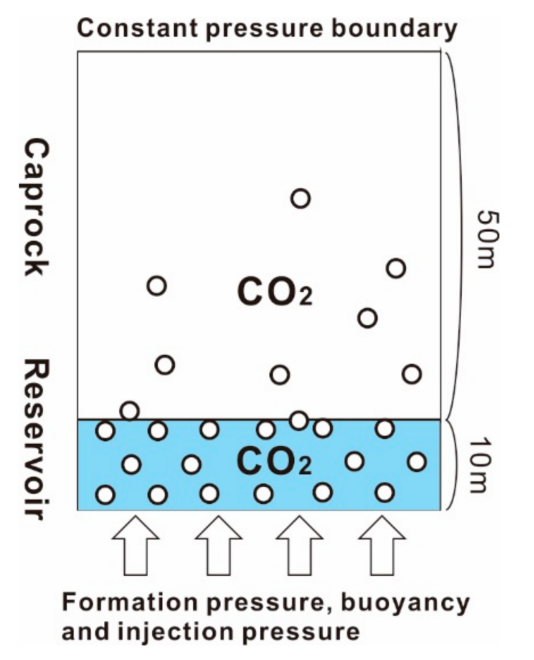

Figure 2. Sketch of the 1D vertical model. 
Table 1. Hydrogeological parameters used in the simulations $[12,32,38]$.

\begin{tabular}{|c|c|c|}
\hline \multirow{2}{*}{ Parameters } & \multicolumn{2}{|c|}{ Formation } \\
\hline & Caprock & Reservoir \\
\hline Porosity & 0.03 & 0.114 \\
\hline Horizontal permeability $\left(10^{-15} \mathrm{~m}^{2}\right)$ & 0.25 & 4.5 \\
\hline Vertical permeability $\left(10^{-15} \mathrm{~m}^{2}\right)$ & 0.025 & 0.45 \\
\hline Pore compressibility $\left(\mathrm{Pa}^{-1}\right)$ & $4.5 \times 10^{-10}$ & $4.5 \times 10^{-10}$ \\
\hline Rock grain density $\left(\mathrm{kg} / \mathrm{m}^{3}\right)$ & 2600 & 2600 \\
\hline Formation heat conductivity $\left(\mathrm{W} / \mathrm{m}{ }^{\circ} \mathrm{C}\right)$ & 2.51 & 2.51 \\
\hline Rock grain specific heat $\left(\mathrm{J} / \mathrm{kg}^{\circ} \mathrm{C}\right)$ & 920 & 920 \\
\hline Temperature $\left({ }^{\circ} \mathrm{C}\right)$ & 53 & 53 \\
\hline Pressure $(\mathrm{MPa})$ & $14.5-15.0$ & 15.5 \\
\hline Salinity (mass fraction) & 0.016 & 0.046 \\
\hline \multicolumn{3}{|c|}{$\begin{array}{l}\text { Relative permeability } \\
\text { guid (van Genuchten, 1980) }\end{array}$} \\
\hline$k_{r l}=\sqrt{S^{*}}\left\{1-\left(1-\left[S^{*}\right]^{1 / m}\right)^{m}\right\}^{2}$. & \multicolumn{2}{|c|}{$S^{*}=\left(S_{l}-S_{l r}\right) /\left(1-S_{l r}\right)$} \\
\hline $\begin{array}{c}\text { Residual liquid saturation } \\
\text { Exponent }\end{array}$ & \multicolumn{2}{|c|}{$\begin{array}{l}S_{l r}=0.30 \\
m=0.457\end{array}$} \\
\hline \multicolumn{3}{|c|}{ Gas (Corey, 1954) } \\
\hline$k_{r g}=(1-\hat{S})^{2}\left(1-\hat{S}^{2}\right)$ & \multirow{2}{*}{\multicolumn{2}{|c|}{$\hat{S}=\left(S_{l}-S_{l r}\right) /\left(S_{l}-S_{l r}-S_{g r}\right)$}} \\
\hline Residual gas saturation & & \\
\hline \multicolumn{3}{|l|}{ Capillary pr } \\
\hline$P_{\text {cap }}=-P_{0}\left(\left[S^{*}\right]^{-1 / m}-1\right)^{1-m}$ & \multicolumn{2}{|c|}{$S^{*}=\left(S_{l}-S_{l r}\right) /\left(1-S_{l r}\right)$} \\
\hline Residual liquid saturation & \multirow{2}{*}{\multicolumn{2}{|c|}{$\begin{array}{l}S_{l r}=0.20 \\
m=0.457\end{array}$}} \\
\hline Exponent & & \\
\hline $\mathrm{P}_{0}(\mathrm{MPa})$ & 2.0 & 1.0 \\
\hline $\mathrm{P}_{\max }(\mathrm{MPa})$ & 100 & 10 \\
\hline
\end{tabular}

\subsection{Initial Mineralogy and Water Geochemistry}

The mass fraction of clay minerals in the bottom of the mudstone caprock (Heshanggou Formation) varies greatly from $13 \%$ to $56 \%$ generated by XRD quantitative analysis of core samples taken from Zhongshenjian 2\#. However, the relative proportion of clay minerals is basically the same, which are mainly composed of smectite and illite, followed by kaolinite and chlorite. Non-clay minerals are mainly composed of quartz, K-feldspar, albite and a small amount of carbonate minerals. The content of clay minerals in the caprock is set to $30 \%$ by fraction of volume to meet the format of TOUGHREACT in defining the mineral abundance in this work. The content of clay minerals in the top of the reservoir (Liujiagou Formation) is 30\%, and non-clay minerals are mainly quartz and feldspar. Almost all possible secondary minerals are considered in the simulations according to previous studies [37,39]. The details of mineral compositions of the caprock and reservoir are shown in Table 2, which is similar to our previous study [38].

The water chemistry of the caprock (Heshanggou Formation) and reservoir (Liujiagou Formation) was derived from water samples that were extracted from Zhongshenjian 2\# at the Shenhua CCS demonstration site and presented in Table 3. Batch geochemical modelling of water-rock interaction was performed to equilibrate the formation water with primary minerals (Table 2) until the desired water chemistry was obtained, where the saturation indices (SI) equal or approximately equal zero. The resulting water chemistry was used as the initial condition for the reactive transport simulation. 
Table 2. Initial mineral volume fractions and possible secondary mineral phases for caprock and reservoir.

\begin{tabular}{|c|c|c|c|}
\hline \multirow{2}{*}{ Mineral } & \multirow{2}{*}{ Chemical Composition } & \multicolumn{2}{|c|}{ Volume Fraction (\%) of Solid Rock } \\
\hline & & Caprock & Reservoir \\
\hline \multicolumn{4}{|l|}{ Primary } \\
\hline Illite & $\mathrm{K}_{0.6} \mathrm{Mg}_{0.25} \mathrm{Al}_{1.8}\left(\mathrm{Al}_{0.5} \mathrm{Si}_{3.5} \mathrm{O}_{10}\right)(\mathrm{OH})_{2}$ & 11.0 & 15.6 \\
\hline Kaolinite & $\mathrm{Al}_{2} \mathrm{Si}_{2} \mathrm{O}_{5}(\mathrm{OH})$ & 3.8 & 4.7 \\
\hline Ca-smectite & $\mathrm{Ca}_{0.145} \mathrm{Mg}_{0.26} \mathrm{Al}_{1.77} \mathrm{Si}_{3.97} \mathrm{O}_{10}(\mathrm{OH})_{2}$ & 10.3 & 5.4 \\
\hline Chlorite & $\mathrm{Mg}_{2.5} \mathrm{Fe}_{2.5} \mathrm{Al}_{2} \mathrm{Si}_{3} \mathrm{O}_{10}(\mathrm{OH})_{8}$ & 4.9 & 4.2 \\
\hline Quartz & $\mathrm{SiO}_{2}$ & 30.0 & 33.5 \\
\hline K-feldspar & $\mathrm{KAlSi}_{3} \mathrm{O}_{8}$ & 7.0 & 10.5 \\
\hline Albite & $\mathrm{NaAlSi}_{3} \mathrm{O}_{8}$ & 8.0 & 15.0 \\
\hline Calcite & $\mathrm{CaCO}_{3}$ & 2.2 & 9.0 \\
\hline Oligoclase & $\mathrm{CaNa}_{4} \mathrm{Al}_{6} \mathrm{Si}_{14} \mathrm{O}_{40}$ & 0 & 2.0 \\
\hline \multicolumn{4}{|l|}{ Secondary } \\
\hline Anhydrite & $\mathrm{CaSO}_{4}$ & & \\
\hline Pyrite & $\mathrm{FeS}_{2}$ & & \\
\hline Hematite & $\mathrm{Fe}_{2} \mathrm{O}_{3}$ & & \\
\hline Siderite & $\mathrm{FeCO}_{3}$ & & \\
\hline Ankerite & $\mathrm{CaMg}_{0.3} \mathrm{Fe}_{0.7}\left(\mathrm{CO}_{3}\right)_{2}$ & & \\
\hline Dawsonite & $\mathrm{NaAlCO}_{3}(\mathrm{OH})_{2}$ & & \\
\hline Magnesite & $\mathrm{MgCO}_{3}$ & & \\
\hline Dolomite & $\mathrm{CaMg}\left(\mathrm{CO}_{3}\right)_{2}$ & & \\
\hline Halite & $\mathrm{NaCl}$ & & \\
\hline
\end{tabular}

Notes. The total volume fraction of reactive minerals should be less than or equal to 1.0. When the total volume fraction of reactive minerals is less than 1.0, the insufficient volume fraction of the whole rock is the default unreactive minerals during the simulation.

Table 3. Initial total dissolved component concentrations $\left(\mathrm{mol} / \mathrm{kg} \mathrm{H}_{2} \mathrm{O}\right)$ for caprock and reservoir.

\begin{tabular}{ccc}
\hline Component & Caprock & Reservoir \\
\hline $\mathrm{Ca}^{2+}$ & $9.424 \times 10^{-2}$ & $3.628 \times 10^{-1}$ \\
$\mathrm{Mg}^{2+}$ & $1.495 \times 10^{-2}$ & $3.728 \times 10^{-2}$ \\
$\mathrm{Na}^{+}$ & $1.620 \times 10^{-1}$ & $3.398 \times 10^{-1}$ \\
$\mathrm{~K}^{+}$ & $9.256 \times 10^{-4}$ & $8.756 \times 10^{-4}$ \\
$\mathrm{Fe}$ & $6.107 \times 10^{-5}$ & $4.000 \times 10^{-5}$ \\
$\mathrm{SiO}_{2}(\mathrm{aq})$ & $1.783 \times 10^{-4}$ & $1.967 \times 10^{-5}$ \\
$\mathrm{C}$ & $3.308 \times 10^{-3}$ & $4.134 \times 10^{-4}$ \\
$\mathrm{SO}_{4}^{2-}$ & $2.141 \times 10^{-2}$ & $2.161 \times 10^{-2}$ \\
$\mathrm{Cl}^{-}$ & $3.467 \times 10^{-1}$ & 1.119 \\
$\mathrm{pH}^{-}$ & 6.94 & 5.35 \\
\hline
\end{tabular}

Notes. Iron is the sum of $\mathrm{Fe}^{2+}, \mathrm{Fe}^{3+}$ and their related complexities; $\mathrm{C}$ is the sum of $\mathrm{CO}_{2}$ (aq) and its related species such as $\mathrm{CO}_{3}{ }^{2-}$ and $\mathrm{HCO}_{3}{ }^{-}$.

\subsection{Simulation Scenarios}

After $\mathrm{CO}_{2}$ is injected into the deep saline aquifers, it may enter the caprock under the action of formation pressure, buoyancy and injection pressure, resulting in complex $\mathrm{CO}_{2}$-water-rock interactions which influence caprock sealing on a geological timescale. We performed all simulations for 5000 years to approximate a scenario of long-term $\mathrm{CO}_{2}$ storage. Mineral composition and formation properties such as temperature, salinity are the key factors that influence the geochemical reaction and caprock sealing capacity, which need further study. Therefore, a series of simulation scenarios were generated by varying one factor relative to a base case (the first simulation using the parameters given in Tables 1-3). These are analyzed to assess how caprock permeability and mineralized $\mathrm{CO}_{2}$ are affected by these parameters, which are listed in Table 4. 
Table 4. Summary of the simulation cases.

\begin{tabular}{ccc}
\hline Simulation Scenarios & Variable Changed & Alternative Value \\
\hline Case 1.1 & Content of K-feldspar & 0 \\
Case 1.2 & Content of albite & 0 \\
\hline Case 2.1 & Temperature $\left({ }^{\circ} \mathrm{C}\right)$ & 63 \\
Case 2.2 & & 73 \\
\hline Case 3.1 & Salinity (mass fraction) & 0.036 \\
Case 3.2 & & 0.056 \\
\hline
\end{tabular}

\section{Results and Discussion}

\subsection{Distribution of Gaseous $\mathrm{CO}_{2}$, Dissolved $\mathrm{CO}_{2}$ and Mineralised $\mathrm{CO}_{2}$ within the Caprock}

After intruding into the caprock, $\mathrm{CO}_{2}$ can be trapped by three phases: gas phase, aqueous phase, and mineral phase (Figure $3 \mathrm{a}-\mathrm{c}$ ). The $\mathrm{CO}_{2}$ gas migrates upward under the action of formation pressure, buoyancy and injection pressure over time. Meanwhile, $\mathrm{CO}_{2}$ dissolves gradually into the formation water forming carbonic acid, $\mathrm{H}_{2} \mathrm{CO}_{3}$, which subsequently dissociates into bicarbonate and carbonate ions, $\mathrm{HCO}_{3}{ }^{-}$and $\mathrm{CO}_{3}{ }^{2-}$. It decreases $\mathrm{pH}$ in the aqueous phase of $\mathrm{CO}_{2}$ altering the initial geochemical equilibrium in the caprock. The spatial variation of $\mathrm{CO}_{2}$ concentration will affect the distribution of $\mathrm{pH}$ and the extent of $\mathrm{CO}_{2}$-water-rock interactions [9,32]. It can be seen that $\mathrm{pH}$ quickly drops from 6.9 to 4.8 following the dissolution of $\mathrm{CO}_{2}$ into groundwater at the bottom of caprock (Figure 3b,d).

(a)

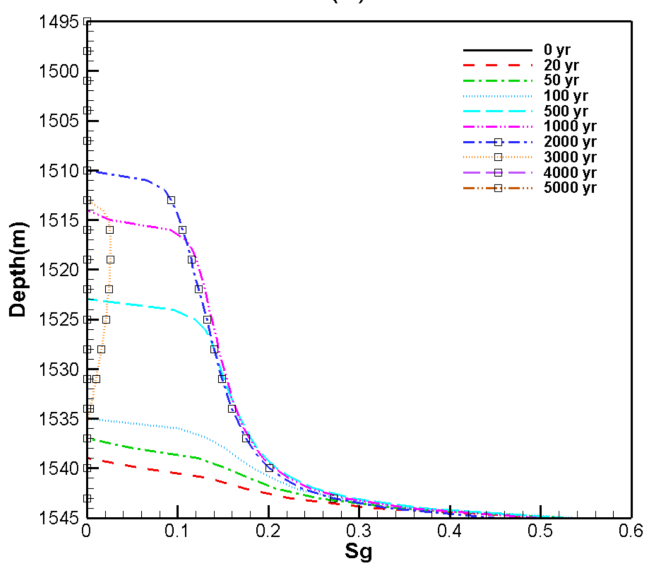

(c)

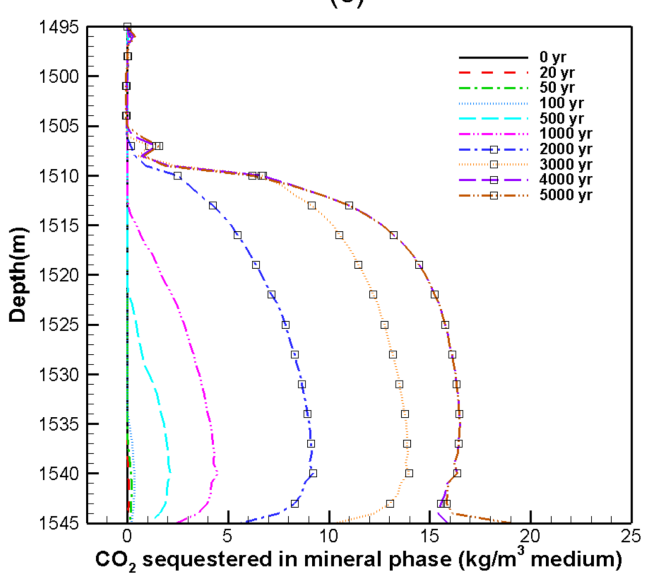

(b)

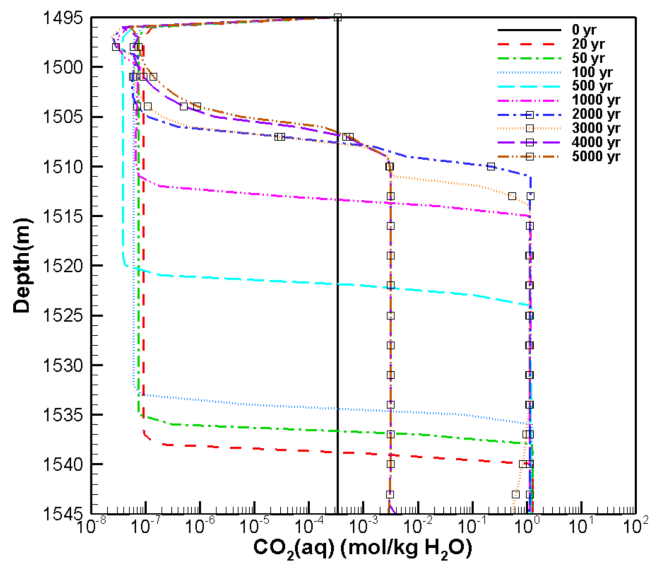

(d)

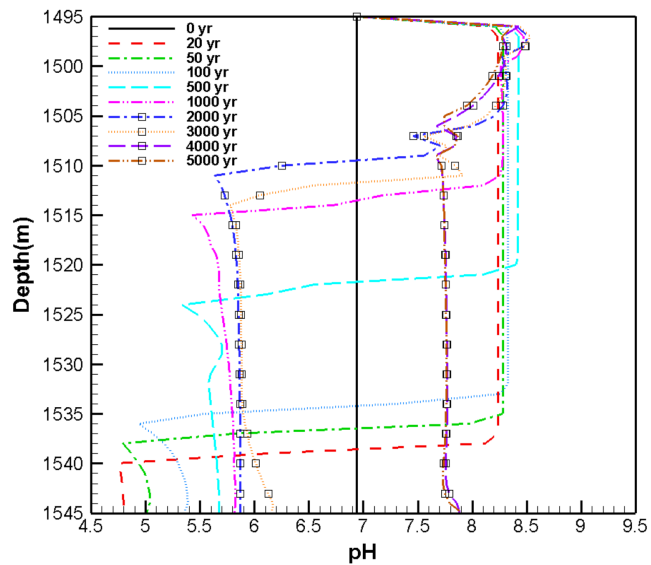

Figure 3. Distribution of gaseous $\mathrm{CO}_{2}(\mathbf{a})$, dissolved $\mathrm{CO}_{2}(\mathbf{b})$, mineralized $\mathrm{CO}_{2}(\mathbf{c})$ and $\mathrm{pH}$ values $(\mathbf{d})$ for different times. 
Over time, $\mathrm{CO}_{2}$ gas phase decreases, but $\mathrm{CO}_{2}$ continues to dissolve in the formation water enhanced by upward migration of the $\mathrm{CO}_{2}$. It can be seen that gaseous $\mathrm{CO}_{2}$ does not penetrate the caprock and is always enclosed in the caprock during the simulation time (Figure 3a). Then, an increasing proportion of $\mathrm{CO}_{2}$ is trapped in mineral phases through the formation of carbonate minerals during the process of $\mathrm{CO}_{2}$-water-rock interactions. As shown in Figure $3 c, \mathrm{CO}_{2}$ sequestered in mineral phases increases gradually from 100 years to the end of the simulation, which is favorable for caprock sealing. Mineral dissolution and precipitation processes are critical for the evolution of caprock sealing performance [35,42], which is very important for long-term $\mathrm{CO}_{2}$ geological storage.

\subsection{Evolution of the Sealing Capacity of Caprock}

During the $\mathrm{CO}_{2}$-water-rock geochemical reactions, the dissolution and precipitation of minerals may lead to changes in caprock porosity and permeability, potentially altering the fluid flow pattern, which could affect the sealing capacity of caprock and thus long-term $\mathrm{CO}_{2}$ geological storage $[39,43]$. The spatial distribution of permeability in caprock is shown in Figure 4, which is consistent with the spatial distribution of $\mathrm{CO}_{2}$ gas saturation (Figure 3a). It can be seen that the permeability tends to decrease in the lower part of the caprock (less than $30 \mathrm{~m}$ ) while increase in the upper part of the caprock. The decrease is mainly because that $\mathrm{CO}_{2}$ infiltrates into the bottom of caprock during long-term storage, resulting in the volume of precipitated minerals (e.g., $\mathrm{CO}_{2}$ trapping minerals, Figure 3c) exceeds that of those dissolved [21,44]. This improves the caprock sealing security (self-sealing). However, in the upper part of caprock unaffected by $\mathrm{CO}_{2}$, the increase in permeability is caused by the long-term water-rock interaction that leading to more mineral dissolution than precipitation. Then, self-dissolution occurs which may decrease the caprock sealing to a certain extent.

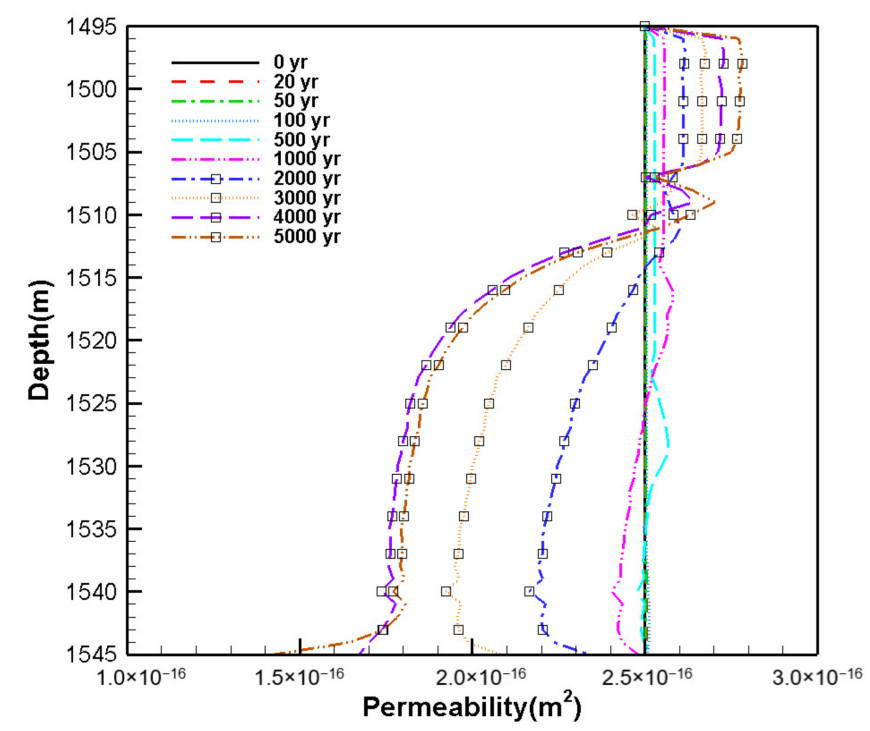

Figure 4. Spatial distribution of permeability in caprock for different times.

\subsection{Analysis of Self-Sealing and Self-Dissolution for Caprock Alteration}

The self-sealing in the lower part of the caprock is induced by more mineral precipitation than dissolution. Among the precipitated minerals, the clay minerals are Ca-smectite and illite, and carbonate minerals are mainly dawsonite, magnesite and siderite, and other silicate mineral such as quartz (Figure 5). The precipitation of carbonate minerals plays a key role in caprock permeability change. As shown in Figures 5e-g and 4, the precipitation of dawsonite, siderite and magnesite are highly consistent with the variation of caprock permeability, which agree well with the distribution of $\mathrm{CO}_{2}$ mineral trapping in caprock (Figure 3c). It can be inferred that the precipitation of carbonate minerals in pores is a common cementation process in mudstone caprock that can reduce or even close advection 
pathways, which is highly advantageous leading to self-sealing of caprock. It is also determined by Charlet et al. [43] and Lo Ré et al. [45]. The precipitation of illite is also favorable for caprock sealing, but its variation is not consistent with other precipitated minerals (Figure $5 b$ ). This might because the precipitation of illite is less affected by $\mathrm{CO}_{2}$ in the system. Lo Ré et al. [45] have also observed illite precipitation both in their water-rock and $\mathrm{CO}_{2}$-water-rock interaction experiments by XRD and SEM analysis, which confirm our results. The dissolution of chlorite, albite, kaolinite, K-feldspar and calcite may increase the caprock permeability to a certain extent. However, they can provide $\mathrm{Mg}^{2+}, \mathrm{Fe}^{2+}, \mathrm{Na}^{+}$, $\mathrm{AlO}_{2}{ }^{-}, \mathrm{K}^{+}$and $\mathrm{Ca}^{2+}$ for the precipitated minerals as mentioned above $[17,31,46]$.

It can be seen that the precipitation of carbonate minerals $\left(\mathrm{CO}_{2}\right.$ trapping minerals) consumes $\mathrm{CO}_{2}$ in caprock, resulting in the decrease in $\mathrm{CO}_{2}$ gas saturation and caprock permeability, which is favorable for enhancing the sealing performance of caprock.

(a)

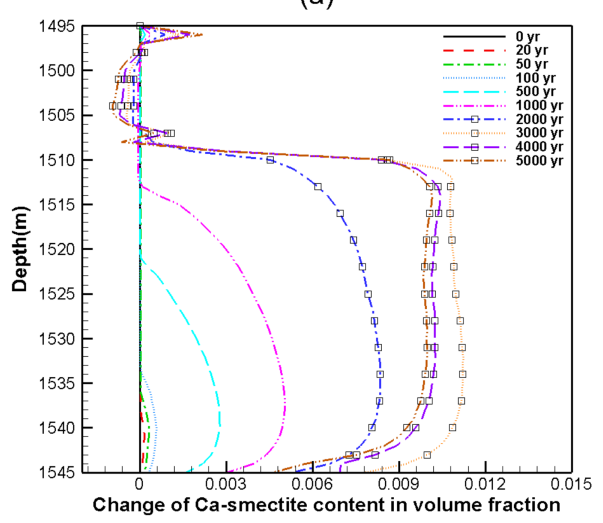

(c)

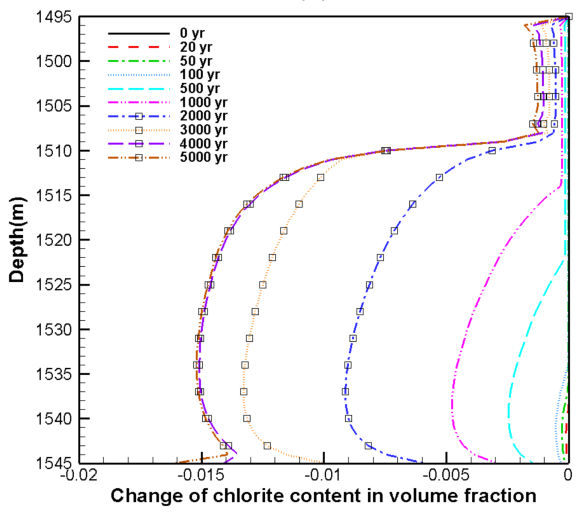

(e)

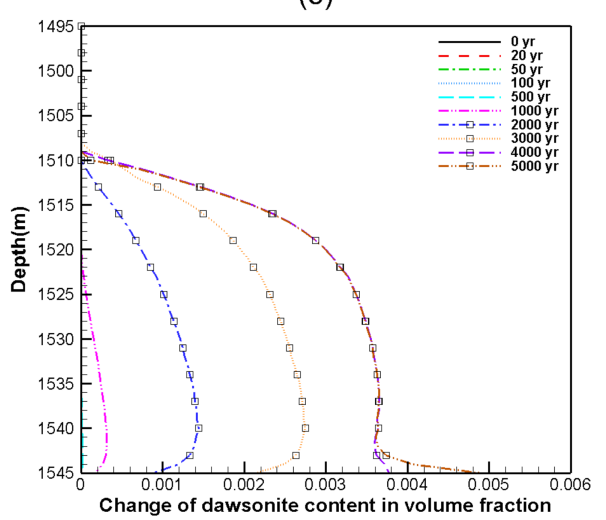

(b)

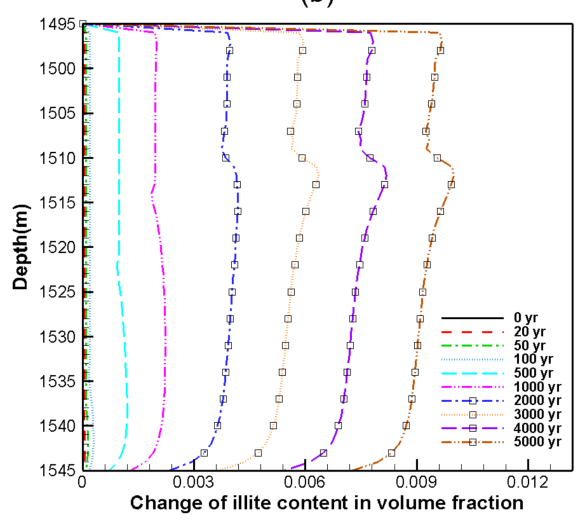

(d)

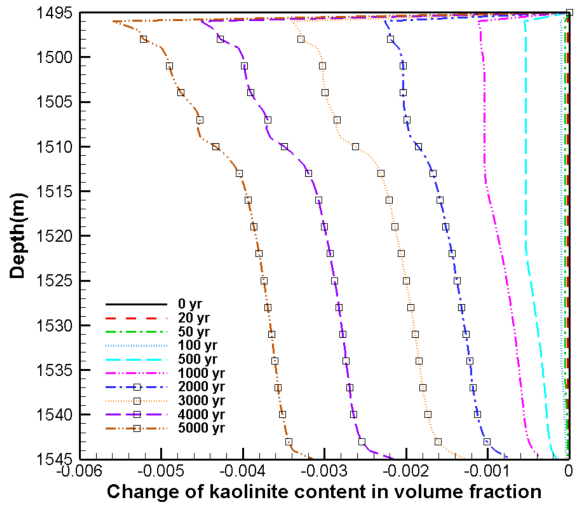

(f)

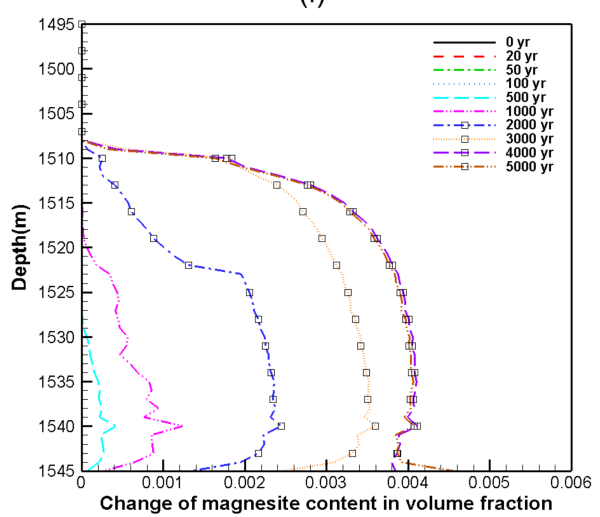

Figure 5. Cont. 
(g)

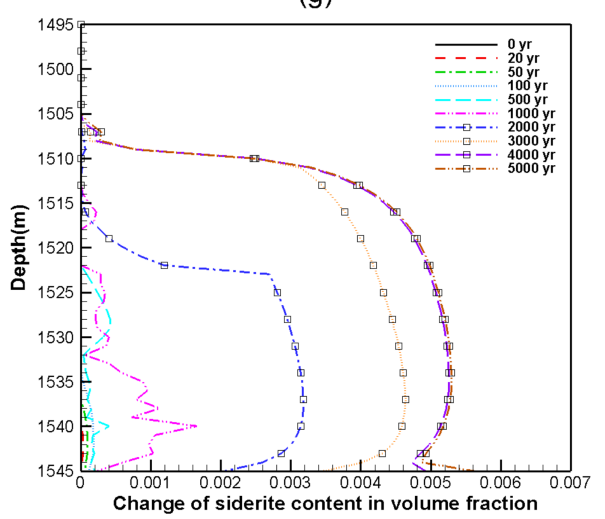

(i)

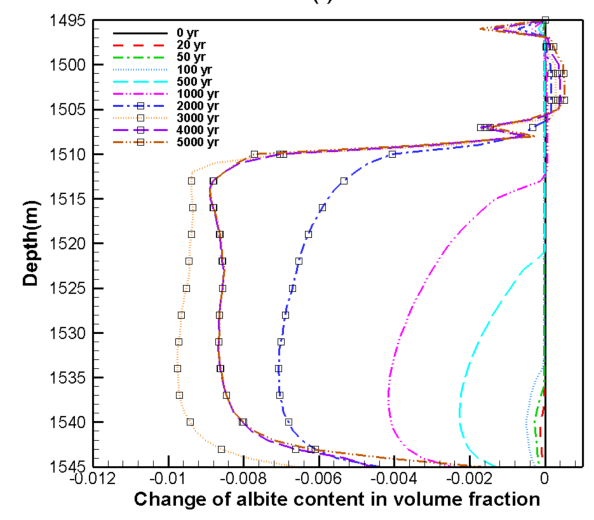

(h)

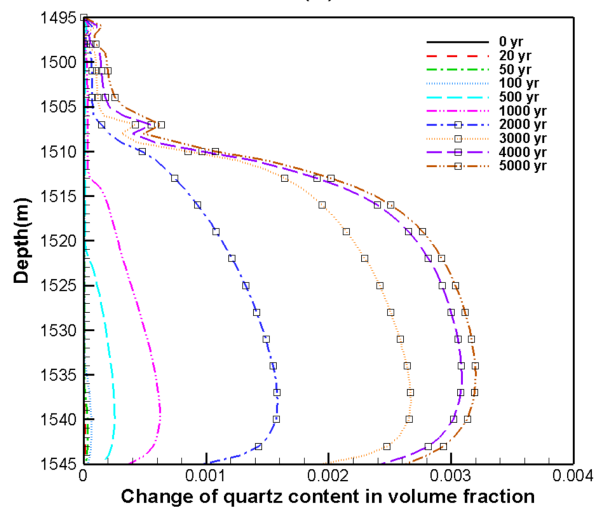

(j)

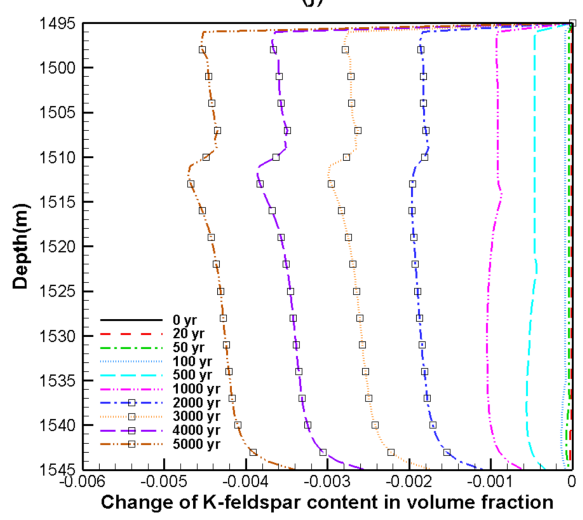

Figure 5. Volume fraction change of clay minerals $(\mathbf{a}-\mathbf{d})$, carbonates $(\mathbf{e}-\mathbf{g})$ and other silicate minerals $(\mathbf{h}-\mathbf{j})$ within the caprock.

Dissolution has occurred in the upper part of caprock (Figure 4). This is mainly due to the dissolution of kaolinite, K-feldspar, chlorite and Ca-smectite during the long-term water-rock interactions. Meanwhile, the precipitation of illite, albite and quartz in the upper part of the caprock can slow down the increase of permeability, but the total amount of mineral dissolution is more than that of mineral precipitation, which results in the increase of permeability in the upper part of the caprock. This is in agreement with experimental studies conducted by Szabó et al. [20] and Lo Ré et al. [45].

The intrusion of $\mathrm{CO}_{2}$ into the caprock changes the geochemical behavior of some minerals. As shown in Figure 5, Ca-smectite and albite in the lower part of caprock show an opposite trend compared with their behaviors in the upper part. It can be seen that $\mathrm{CO}_{2}$-water-rock interaction promotes the precipitation of Ca-smectite and quartz and dissolution of chlorite to a certain extent. Meanwhile, it changes albite from precipitation to dissolution and inhibits the dissolution of kaolinite. As can be seen from Figure 6, the changes in concentration of $\mathrm{K}^{+}, \mathrm{Ca}^{2+}, \mathrm{Na}^{+}, \mathrm{Mg}^{2+}, \mathrm{Fe}^{2+}$ and $\mathrm{AlO}_{2}{ }^{-}$in the system are complex. The ion concentrations vary generally greater in the lower part of the caprock induced by $\mathrm{CO}_{2}$ than in the upper part without $\mathrm{CO}_{2}$. Concentrations of $\mathrm{K}^{+}, \mathrm{Na}^{+}, \mathrm{Mg}^{2+}$, and $\mathrm{Fe}^{2+}$ appear to increase initially and then decrease irregularly over time in the lower part of the caprock, while $\mathrm{AlO}_{2}{ }^{-}$concentration decreases initially then increases over time. This suggest the complex mutual transformation of $\mathrm{K}^{+}, \mathrm{Na}^{+}, \mathrm{Mg}^{2+}, \mathrm{Fe}^{2+}$ and $\mathrm{AlO}_{2}{ }^{-}$-bearing minerals during $\mathrm{CO}_{2}$-water-caprock geochemical process [22,42]. $\mathrm{Ca}^{2+}$ concentration decreases irregularly over time and is relatively constant at the end of the simulation, suggesting that steady state is established between the fluid and calcium-bearing minerals [45]. 
(a)

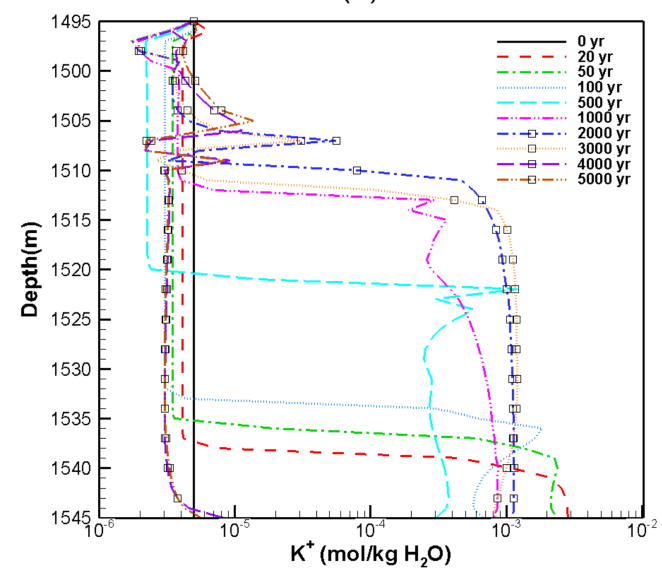

(c)

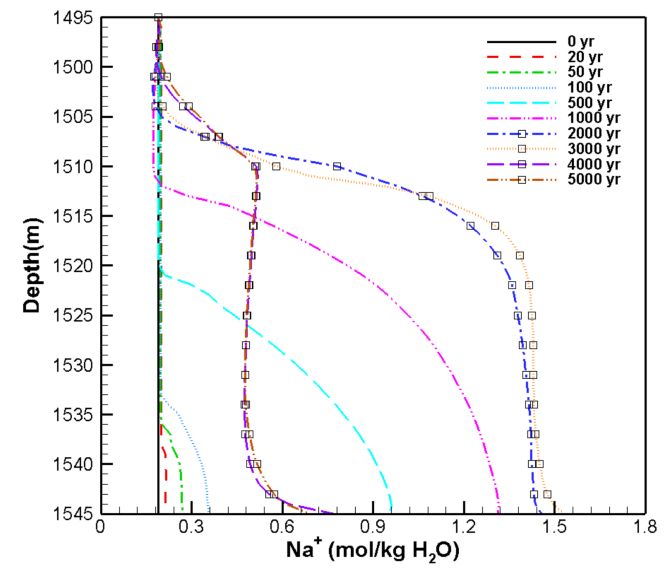

(e)

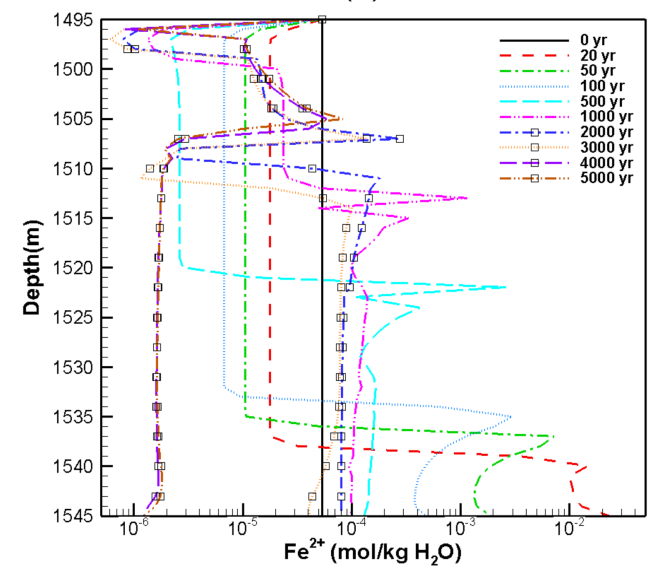

(b)

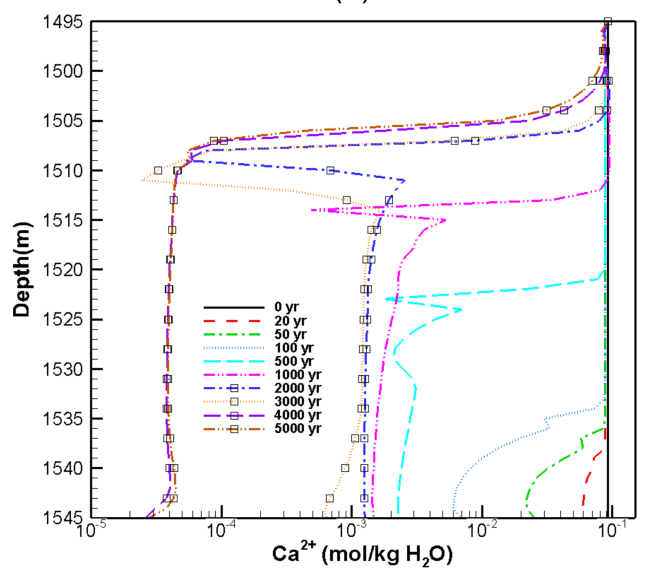

(d)

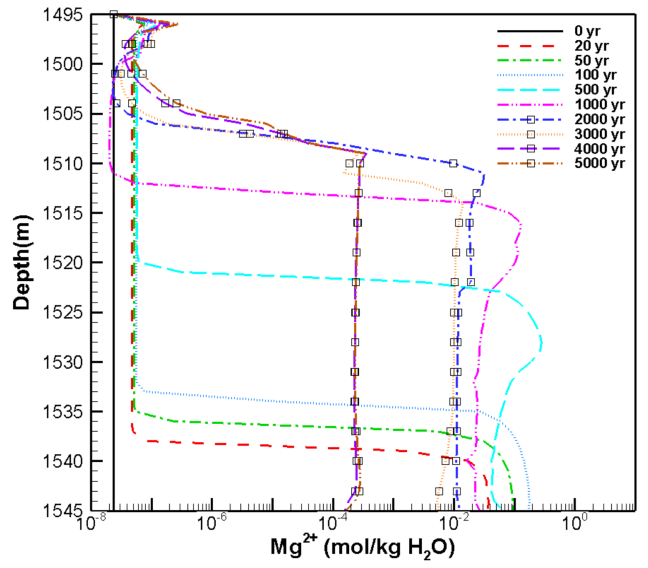

(f)

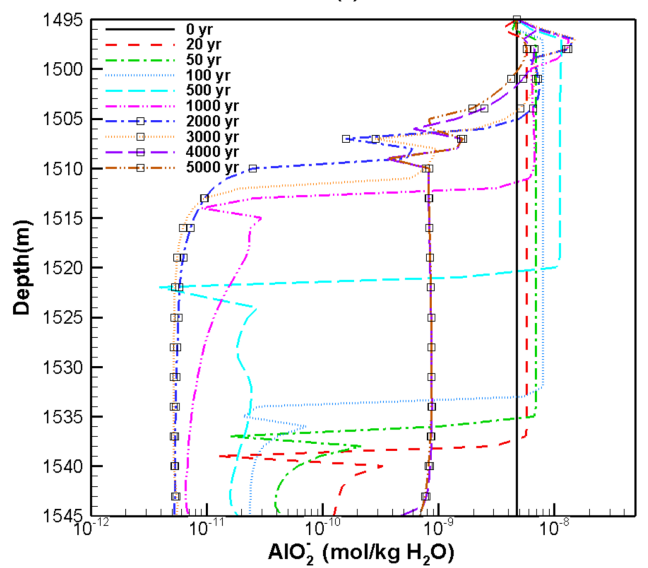

Figure 6. Concentrations (in $\mathrm{mol} / \mathrm{kg} \mathrm{H}_{2} \mathrm{O}$ ) of aqueous chemical components within the caprock. (a) $\mathrm{K}^{+}$; (b) $\mathrm{Ca}^{2+} ;$ (c) $\mathrm{Na}^{+} ;$(d) $\mathrm{Mg}^{2+} ;$ (e) $\mathrm{Fe}^{2+} ;$ (f) $\mathrm{AlO}_{2}{ }^{-}$. Note that the values of ion concentrations are presented on a log scale except for the high concentrations of $\mathrm{Na}^{+}$.

The dissolution of albite, K-feldspar, chlorite and calcite supplies required ions for the precipitation of illite, Ca-smectite, dawsonite, magnesite and siderite in the caprock. It can be seen that the dissolution behavior of K-feldspar is highly consistent with that of illite precipitation (Figure $5 b, j$ ), suggesting the dissolution of K-feldspar corresponds with illite formation. The study of $\mathrm{Xu}$ et al. [34] also shows that illite precipitates due to the dissolution of $\mathrm{K}$-feldspar. It can be inferred that the dissolution of $\mathrm{K}$-feldspar $\left(\mathrm{KAlSi}_{3} \mathrm{O}_{8}\right)$ provides $\mathrm{K}^{+}$for the precipitation of illite $\left(\mathrm{K}_{0.6} \mathrm{Mg}_{0.25} \mathrm{Al}_{1.8}\left(\mathrm{Al}_{0.5} \mathrm{Si}_{3.5} \mathrm{O}_{10}\right)(\mathrm{OH})_{2}\right)$. 
The dissolution of chlorite has a great effect on $\mathrm{Mg}^{2+}$ and $\mathrm{Fe}^{2+}$-bearing minerals precipitation, which can provide $\mathrm{Mg}^{2+}$ and $\mathrm{Fe}^{2+}$ for the precipitation of illite, Ca-smectite, magnesite and siderite [37,47]. Calcite dissolution could provide the required $\mathrm{Ca}^{2+}$ for the precipitation of calcium-bearing minerals. Dissolution of feldspar, chlorite and calcite, and the formation of dawsonite are also observed in the Permian Supai Formation of the Springerville-St. John $\mathrm{CO}_{2}$ field, USA [48], which is in general agreement with our results.

It can be inferred that the self-sealing and self-dissolution of caprock depend on minerals dissolution and precipitation over the long-term $\mathrm{CO}_{2}$-water-rock interactions. When mineral precipitation is greater than dissolution, the caprock permeability decreases, leading to the self-sealing phenomenon, which is favorable for enhancing the sealing capacity of caprock. On the contrary, when mineral dissolution is greater than precipitation, the caprock permeability increases, thus self-dissolution phenomenon occurs that may decrease the sealing capacity of the caprock.

\subsection{Sensitivity Analyses}

\subsubsection{Influence of Mineral Composition}

Through the above analysis, it is found that K-feldspar is the key mineral causing the self-dissolution and self-sealing of the caprock. In order to investigate the influence of K-feldspar on the sealing capacity of caprock, we set the content of K-feldspar to 0, that is, there is no K-feldspar in the caprock (Case 1.1). As presented in Figure 7a, the permeability of the caprock decreases obviously compared to the base case. It can be seen that the permeability decreases to $52 \%$ of initial permeability at the end of the simulation (i.e., 5000 years) without $\mathrm{K}$-feldspar dissolution. However, mineralized $\mathrm{CO}_{2}$ increases compared to the base case (Figure $7 \mathrm{~b}$ ), which could explain the decrease of permeability in the lower part of caprock from another aspect. As can be seen from Figure 7c, there is no illite precipitation when K-feldspar is absent as a primary mineral. This confirms that illite formation is due to the dissolution of K-feldspar, which is consistent with previous studies [7,34,47]. Those studies also suggest that $\mathrm{K}^{+}$and $\mathrm{AlO}_{2}{ }^{-}$required for illite precipitation are supplied by the dissolution of $\mathrm{K}$-feldspar that agree well with our results. Meanwhile, the dissolution of albite and precipitation of Ca-smectite in the lower part of the caprock are promoted in the absence of K-feldspar (Figure 7d,e).

In order to investigate the abundance of albite on the sealing capacity of caprock, we set the content of albite to 0 (Case 1.2). It can be seen that the minimum value $(0.144 \mathrm{mD})$ of caprock permeability reduces to $56 \%$ of the initial value in the base case (Figure 7a). As shown in Figure 7e, the precipitation of Ca-smectite decreases significantly in the lower part of the caprock in the absence of albite. Simultaneously, the minimum value of caprock permeability decreases to $0.17 \mathrm{mD}$ at the bottom of the caprock, approximately $68 \%$ of the initial value, while the permeability increases to $136 \%$ of the initial value at the top of the caprock (Figure 7a). This is mainly because that the precipitation of Ca-smectite is limited to a great extent without albite dissolution, however, it promotes the dissolution of K-feldspar and the precipitation of illite (Figure 7c,f). It can be seen that mineralized $\mathrm{CO}_{2}$ also decreases compared to the base case (Figure $7 \mathrm{~b}$ ), which can be explained that there is no albite dissolution providing sufficient $\mathrm{Na}^{+}$for dawsonite precipitation [49]. An example by Tambach et al. [50] also shows that the $\mathrm{Na}^{+}$released from albite is consumed by dawsonite precipitation, and K-feldspar is transformed into illite. This is in good agreement with our modelling results.

Therefore, it can be inferred that the dissolution of K-feldspar provides required $\mathrm{K}^{+}$for illite precipitation, and albite is the key mineral affecting Ca-smectite precipitation. When K-feldspar is absent in the system, self-dissolution is obviously weakened in the upper part of the caprock, and self-sealing is obviously enhanced in the lower part of the caprock, which is favorable for long-term $\mathrm{CO}_{2}$ storage. When albite is absent in the system, self-dissolution of the caprock is enhanced, and self-sealing is weakened, which is not conducive to the sealing capacity of the caprock and the long-term $\mathrm{CO}_{2}$ storage. 
(a)

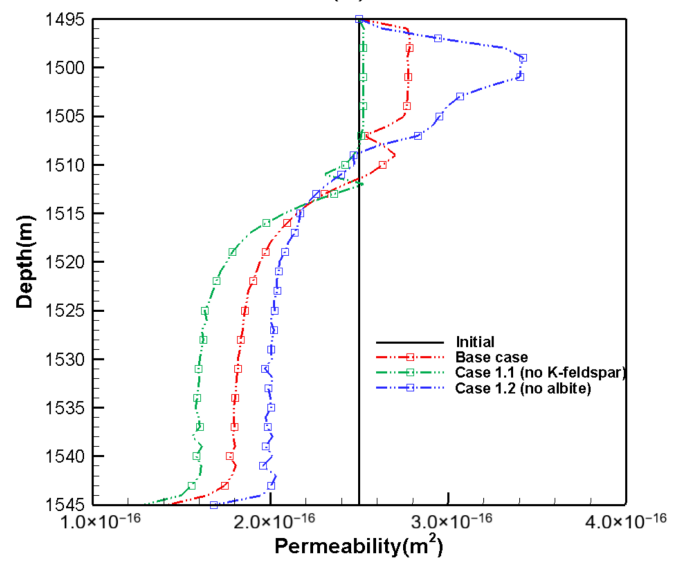

(c)

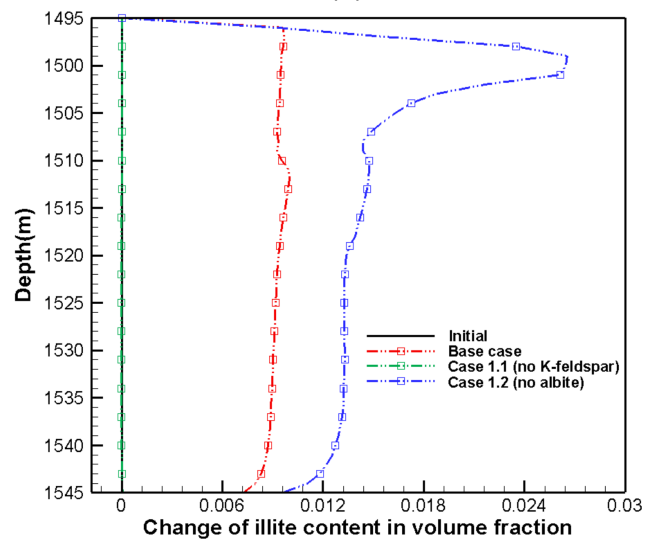

(e)

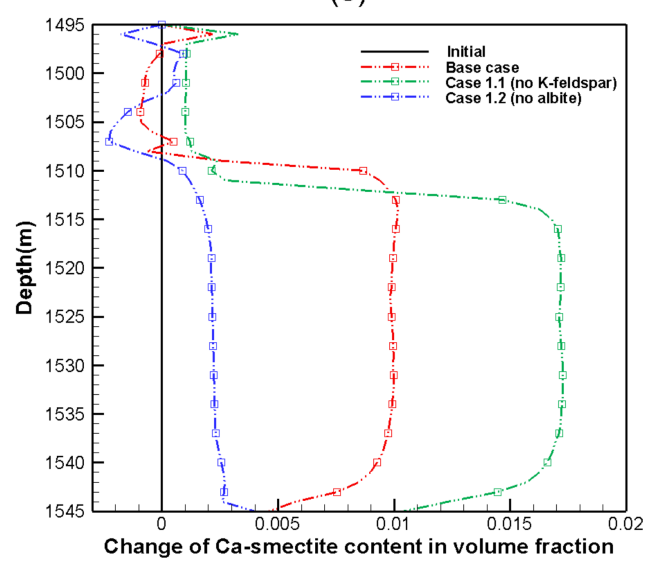

(b)

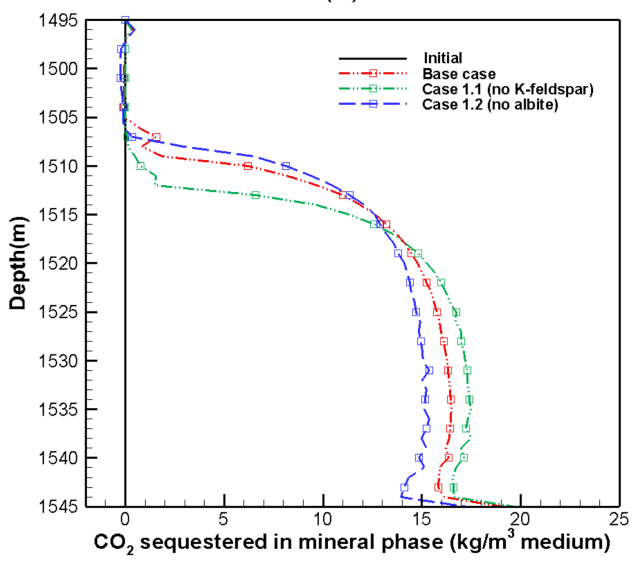

(d)

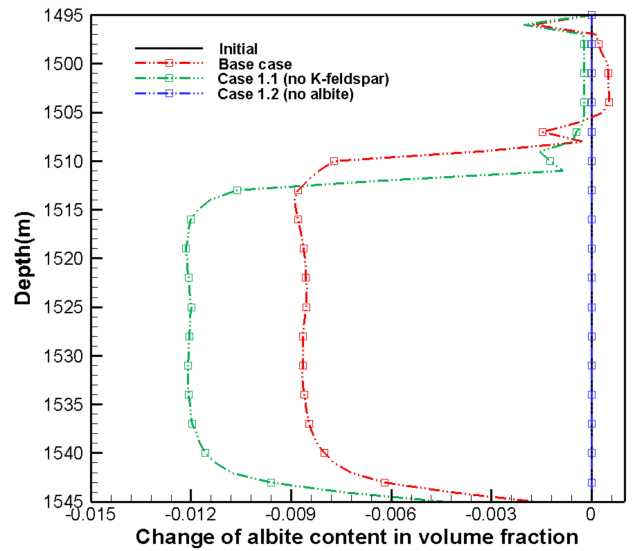

(f)

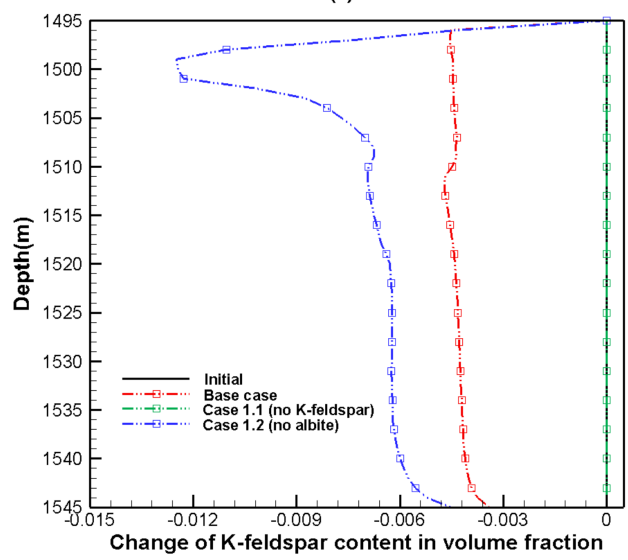

Figure 7. Spatial distribution of permeability (a), and mineralized $\mathrm{CO}_{2}(\mathbf{b})$, and abundance (in volume fraction) of illite (c), albite (d), Ca-smectite (e), K-feldspar (f) within the caprock at the end of the simulation (i.e., 5000 years) obtained with three different mineral compositions.

\subsubsection{Influence of Formation Temperature}

The formation temperature varies with the depth of the aquifer and has a great effect on caprock sealing during long-term $\mathrm{CO}_{2}$ geological storage. As shown in Figure 8a, the increase of temperature accelerates the decrease of permeability at the base of the caprock, and the vertical distribution range of permeability at the base also decreases with increasing temperature. Meanwhile, the permeability in the upper part of the caprock reaches $0.53 \mathrm{mD}$ by the end of the simulation, increasing more than $210 \%$ from the initial value when the formation temperature is $73^{\circ} \mathrm{C}$. The results 
suggest that self-sealing and self-dissolution of the caprock are enhanced with increasing formation temperature. This is mainly because the reaction rate of minerals increases greatly with the increase in temperature, thus strengthening the dissolution and precipitation of minerals, leading to significant changes in caprock permeability $[25,33,35,51]$. Under the domination of mineral precipitation in the $\mathrm{CO}_{2}$-water-rock interaction, the precipitation further increases as the temperature increases, enhancing the self-sealing of caprock. For the upper part of the caprock, mineral dissolution dominates the water-rock interaction process increasing with increasing temperature, which leads to significant self-dissolution [20]. Similar observations are also reported by Liu et al. [17] and Jayasekara et al. [16] in experiment interactions between $\mathrm{CO}_{2}$, caprock and brine.

(a)

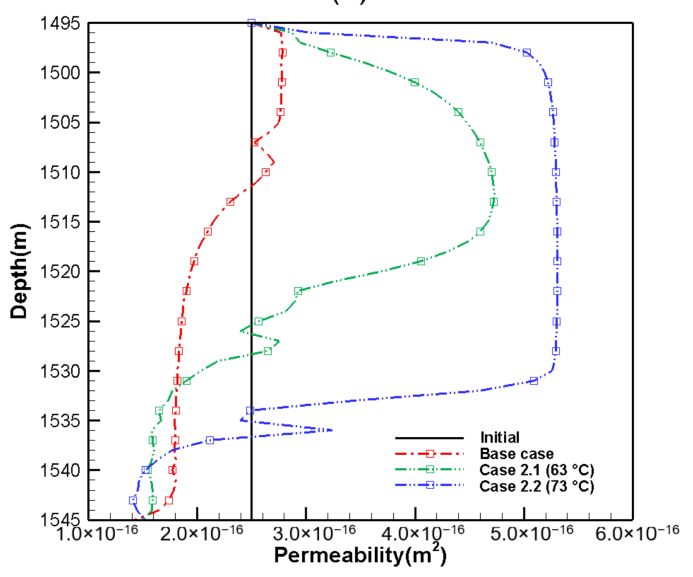

(c)

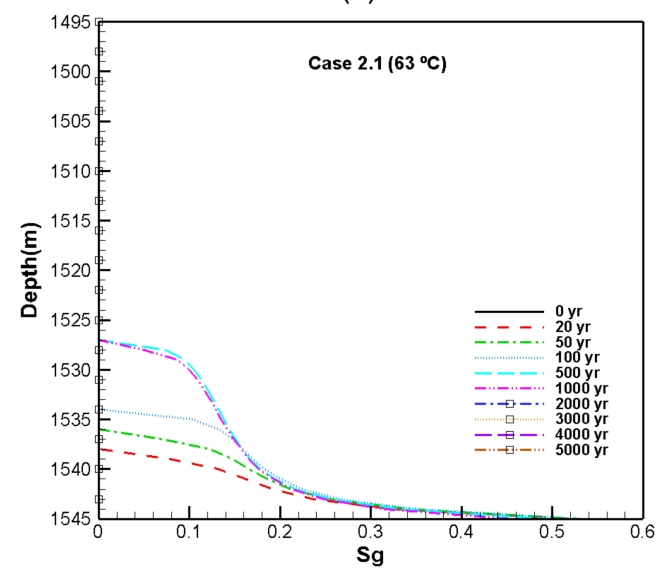

(b)

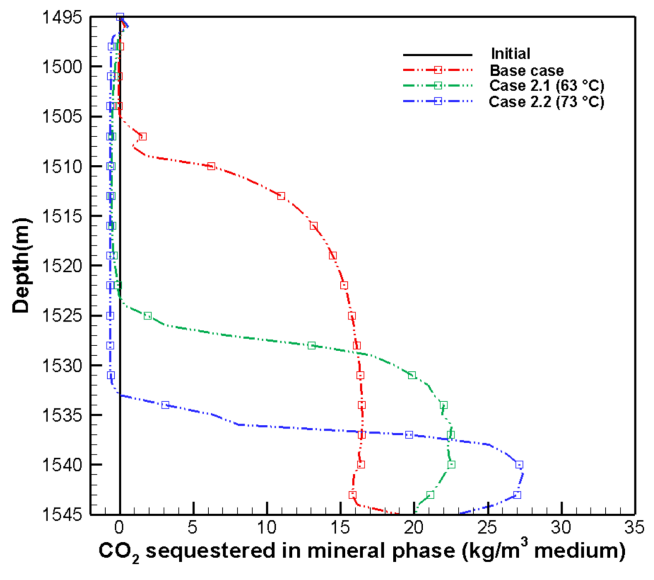

(d)

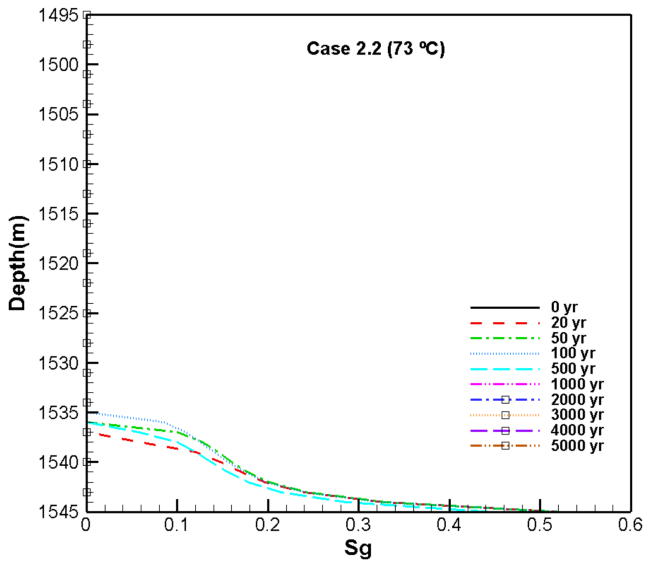

Figure 8. Changes in caprock permeability (a), mineralized $\mathrm{CO}_{2}(\mathbf{b})$ and $\mathrm{CO}_{2}$ gas saturation (c,d) within the caprock for different temperatures.

It can be seen that $\mathrm{CO}_{2}$ gas saturation decreases gradually from the base to the top of the caprock (Figures $3 \mathrm{a}$ and $8 \mathrm{c}, \mathrm{d}$ ). Meanwhile, the upward migration distance of gaseous $\mathrm{CO}_{2}$ in caprock decreases with increasing temperature. There is basically no gaseous $\mathrm{CO}_{2}$ after 100 years when the formation temperature is $73^{\circ} \mathrm{C}$. Then, the $\mathrm{CO}_{2}$-water-rock interaction begins to weaken due to the dissolved $\mathrm{CO}_{2}$ in caprock not being replenished over time and consumed gradually. Although the maximum value of mineralized $\mathrm{CO}_{2}$ increases with increasing temperature, reaching $27.5 \mathrm{~kg} / \mathrm{m}^{3}$ medium (Figure $3 \mathrm{i}$ ), the vertical distribution decreases significantly, corresponding to the upward migration of gaseous $\mathrm{CO}_{2}$ (Figure $8 \mathrm{~d}$ ). Thus, the total mineralized $\mathrm{CO}_{2}$ within the caprock may decrease significantly with increasing temperature. These results suggest that the increase of formation temperature accelerates the geochemical process of $\mathrm{CO}_{2}$, caprock and brine, which can consume $\mathrm{CO}_{2}$ quickly and slow down the upward migration of $\mathrm{CO}_{2}$ effectively within the caprock $[16,33]$. However, self-dissolution in the 
upper part of the caprock is enhanced significantly due to the higher temperature, which may decrease the sealing capacity of the caprock.

\subsubsection{Influence of Salinity}

The effect of salinity on caprock sealing is evaluated by evaporating the initial formation water to increase salinity to 3.6 and $5.6 \mathrm{wt}$.\% dissolved $\mathrm{NaCl}$. As shown in Figure 9, the changes in caprock permeability and mineralized $\mathrm{CO}_{2}$ are nearly the same for the different salinities. Although the salinity of the formation water increases to $5.6 \mathrm{wt} . \%$, the effect on the caprock sealing and mineralized $\mathrm{CO}_{2}$ is negligible. It is quite consistent with [46] that the formation water salinity has a negligible effect on the mineralization potential for $\mathrm{CO}_{2}$. However, it is different from other studies where the increase of salinity enhances the ionic strength of the solution, reducing mineral dissolution and increasing mineral precipitation (e.g., deposition of different types of evaporites in rock pores) in the caprock, leading to a significant reduction in caprock permeability and decrease in $\mathrm{CO}_{2}$ storage capacity at high salinity concentrations in brine [52-54]. This is probably because the salinity level in our study is so low that there is no significant effect on mineral alteration and consequent permeability changes and mineralized $\mathrm{CO}_{2}$.

(a)

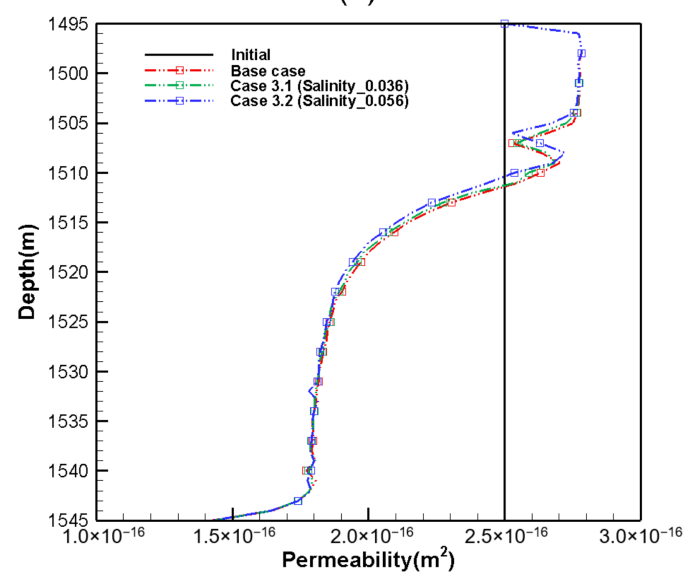

(b)

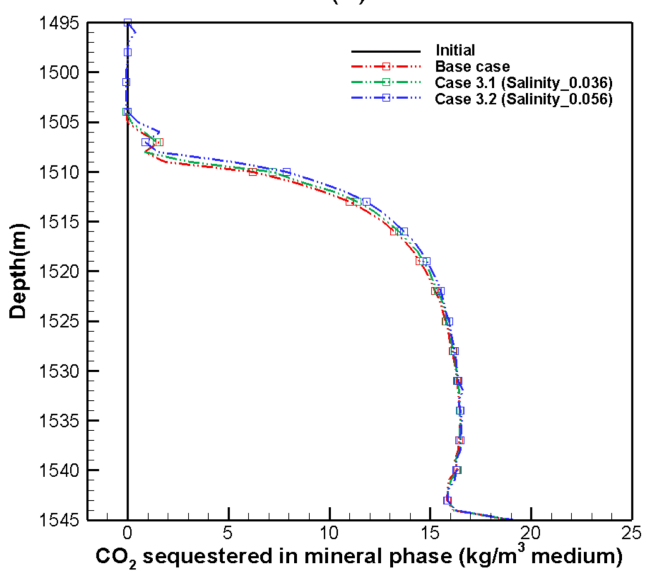

Figure 9. Changes in caprock permeability (a) and mineralized $\mathrm{CO}_{2}$ (b) within the caprock for different salinity.

\section{Conclusions}

This study investigates the evolution of seal capacity of caprock induced by mineral alteration using TOUGHREACT based on the Heshanggou Formation mudstone at the Shenhua CCS demonstration site of China. The following conclusions can be drawn:

(1) The $\mathrm{CO}_{2}$ gas migrates upward under the action of formation pressure, buoyancy and injection pressure over time, then gradually decreases due to dissolution and the formation of carbonate minerals. Gaseous $\mathrm{CO}_{2}$ does not break through the caprock and is always enclosed in the caprock during the simulation time. Mineralized $\mathrm{CO}_{2}$ increases gradually from 100 years to the end of the simulation that is favorable for caprock sealing.

(2) The self-sealing phenomenon occurs in the lower part of the caprock dominated by the precipitation of dawsonite, magnesite, siderite, Ca-smectite and illite during long-term $\mathrm{CO}_{2}$-water-rock geochemical reactions, which is favorable for enhancing the sealing capacity of the caprock. On the contrary, self-dissolution occurs in the upper part of caprock mainly due to the dissolution of kaolinite, K-feldspar, chlorite and Ca-smectite, which may decrease the sealing capacity of caprock. 
(3) The precipitation of dawsonite, magnesite, siderite and other carbonate minerals can reduce or even close advection pathways with albite and chlorite providing $\mathrm{Na}^{+}, \mathrm{Mg}^{2+}$ and $\mathrm{Fe}^{2+}$, which is highly advantageous, leading to self-sealing of the caprock. K-feldspar and albite are the key minerals causing the self-dissolution and self-sealing of the caprock. The dissolution of K-feldspar dominates illite precipitation by providing required $\mathrm{K}^{+}$, and albite affects the precipitation of Ca-smectite. When K-feldspar is absent as a primary mineral, the self-dissolution is weakened in the upper part of the caprock, and the self-sealing is obviously enhanced with mineralized $\mathrm{CO}_{2}$ increasing in the lower part of the caprock, which is favorable for long-term $\mathrm{CO}_{2}$ storage. When albite is absent, the self-dissolution of the caprock is enhanced, and self-sealing is weakened with mineralized $\mathrm{CO}_{2}$ decreasing, which is not conducive to long-term $\mathrm{CO}_{2}$ storage.

(4) Formation temperature has a great effect on the sealing capacity of caprock. The self-sealing and self-dissolution of caprock are enhanced with increasing temperature because the kinetic reaction rate of minerals increases greatly with the increase of temperature strengthening the dissolution and precipitation of minerals. Meanwhile, the upward migration distance of gaseous $\mathrm{CO}_{2}$ in the caprock decreases with increasing temperature due to the accelerated geochemical process of $\mathrm{CO}_{2}$, caprock and brine. However, the self-dissolution in the upper part of the caprock is enhanced significantly due to the high temperature that may result in a decrease of the sealing capacity of the caprock. The effect of salinity on the caprock sealing and mineralized $\mathrm{CO}_{2}$ is negligible in this study mainly because the salinity level of the formation water in the Heshanggou Formation is so low.

In summary, we present a geochemical modelling study of the evolution of caprock sealing capacity in the Heshanggou Formation mudstone at the Shenhua CCS pilot of China. Results from this study are useful for the evaluation of geochemical behavior of caprock for practical implementations of CCS, providing a useful insight for screening the most effective caprocks and assessing the safety of long-term $\mathrm{CO}_{2}$ geological storage by considering caprock compositions and in situ conditions. As future recommendations, it is necessary to determine the kinetic rate and thermodynamic properties of minerals as well as the process of precipitation and dissolution of the caprock matrix.

Author Contributions: G.Y. and X.M. conceived and designed the methodology; X.M., T.F., and S.Y. performed the numerical simulations and data analyses; G.Y., Y.Y., and M.H. wrote, edited and reviewed the manuscript, X.M. and Y.W. handled project administration and secured funding. All authors have read and agreed to the published version of the manuscript.

Funding: This work was supported by the National Natural Science Foundation of China (NSFC, Grant No. 41602272 and 41702284), the Project supported by Natural Science Foundation of Hubei Province, China (Grant No. 2019CFB451), the China Australia Geological Storage of $\mathrm{CO}_{2}$ Project (CAGS), and the Open Fund of Hubei Key Laboratory of Marine Geological Resources (MGR202003).

Acknowledgments: The authors are grateful to Fei Cheng and Ming Li for fruitful discussions and Matthew Myers for reviewing the manuscript. The authors would like to express their gratitude to the editor and anonymous reviewers for their insightful comments and suggestions, which are helpful in improving the quality of the manuscript.

Conflicts of Interest: The authors declare no conflict of interest.

\section{References}

1. Metz, B.; Davidson, O.; De Coninck, H.; Loos, M.; Meyer, L. IPCC Special Report on Carbon Dioxide Capture and Storage; Cambridge University Press: Cambridge, UK, 2005.

2. Bachu, S. Sequestration of $\mathrm{CO}_{2}$ in geological media in response to climate change: Road map for site selection using the transform of the geological space into the $\mathrm{CO}_{2}$ phase space. Energy Convers. Manag. 2002, 43, 87-102. [CrossRef]

3. Benson, S.M.; Cole, D.R. $\mathrm{CO}_{2}$ Sequestration in Deep Sedimentary Formations. Elements 2008, 4, 325-331. [CrossRef]

4. Randolph, J.B.; Saar, M.O. Combining geothermal energy capture with geologic carbon dioxide sequestration. Geophys. Res. Lett. 2011, 38, L10401. [CrossRef] 
5. Li, Q.; Chen, Z.; Zhang, J.; Liu, L.; Li, X.; Jia, L. Positioning and revision of CCUS technology development in China. Int. J. Greenh. Gas Control 2016, 46, 282-293. [CrossRef]

6. Jiao, Z.; Zhou, L.; Gao, R.; Luo, T.; Wang, H.; Wang, H.; McLaughlin, F.; Bentley, R.; Quillinan, S. Opportunity and challenges of integrated enhanced oil recovery using $\mathrm{CO}_{2}$ flooding with geological $\mathrm{CO}_{2}$ storage in the Ordos Basin, China. Energy Procedia 2014, 63, 7761-7771. [CrossRef]

7. Gaus, I.; Azaroual, M.; Czernichowski-Lauriol, I. Reactive transport modelling of the impact of $\mathrm{CO}_{2}$ injection on the clayey caprock at Sleipner (North Sea). Chem. Geol. 2005, 217, 319-337. [CrossRef]

8. Dance, T.; Spencer, L.; Xu, J.-Q. Geological characterisation of the Otway project pilot site: What a difference a well makes. Energy Procedia 2009, 1, 2871-2878. [CrossRef]

9. Rutqvist, J.; Vasco, D.W.; Myer, L. Coupled reservoir-geomechanical analysis of $\mathrm{CO}_{2}$ injection and ground deformations at In Salah, Algeria. Int. J. Greenh. Gas Control 2010, 4, 225-230. [CrossRef]

10. Rostron, B.; Whittaker, S. 10+ years of the IEA-GHG Weyburn-Midale $\mathrm{CO}_{2}$ monitoring and storage project: Successes and lessons learned from multiple hydrogeological investigations. Energy Procedia 2011, 4, 3636-3643. [CrossRef]

11. Lu, J.; Kharaka, Y.K.; Thordsen, J.J.; Horita, J.; Karamalidis, A.; Griffith, C.; Hakala, J.A.; Ambats, G.; Cole, D.R.; Phelps, T.J.; et al. $\mathrm{CO}_{2}$-rock-brine interactions in Lower Tuscaloosa Formation at Cranfield $\mathrm{CO}_{2}$ sequestration site, Mississippi, USA. Chem. Geol. 2012, 291, 269-277. [CrossRef]

12. Wu, X. Carbon Dioxide Capture and Geological Storage: The First Massive Exploration in China; Science Press: Beijing, China, 2013.

13. Gaus, I. Role and impact of $\mathrm{CO}_{2}$-rock interactions during $\mathrm{CO}_{2}$ storage in sedimentary rocks. Int. J. Greenh. Gas Control 2010, 4, 73-89. [CrossRef]

14. Boulin, P.F.; Bretonnier, P.; Vassil, V.; Samouillet, A.; Fleury, M.; Lombard, J.M. Sealing efficiency of caprocks: Experimental investigation of entry pressure measurement methods. Mar. Pet. Geol. 2013, 48, 20-30. [CrossRef]

15. Park, J.; Yang, M.; Kim, S.; Lee, M.; Wang, S. Estimates of $\mathrm{scCO}_{2}$ Storage and Sealing Capacity of the Janggi Basin in Korea Based on Laboratory Scale Experiments. Minerals 2019, 9, 515. [CrossRef]

16. Jayasekara, D.W.; Ranjith, P.G.; Wanniarachchi, W.A.M.; Rathnaweera, T.D. Understanding the chemico-mineralogical changes of caprock sealing in deep saline $\mathrm{CO}_{2}$ sequestration environments: A review study. J. Supercrit. Fluids 2020, 161, 104819. [CrossRef]

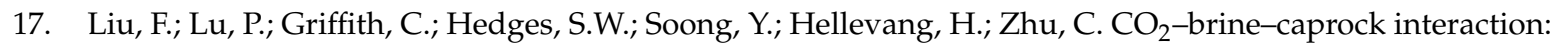
Reactivity experiments on Eau Claire shale and a review of relevant literature. Int. J. Greenh. Gas Control 2012, 7, 153-167. [CrossRef]

18. Song, J.; Zhang, D. Comprehensive review of caprock-sealing mechanisms for geologic carbon sequestration. Environ. Sci. Technol. 2013, 47,9-22. [CrossRef]

19. Iglauer, S.; Pentland, C.H.; Busch, A. $\mathrm{CO}_{2}$ wettability of seal and reservoir rocks and the implications for carbon geo-sequestration. Water Resour. Res. 2015, 51, 729-774. [CrossRef]

20. Szabó, Z.; Hellevang, H.; Király, C.; Sendula, E.; Kónya, P.; Falus, G.; Török, S.; Szabó, C. Experimental-modelling geochemical study of potential CCS caprocks in brine and $\mathrm{CO}_{2}$-saturated brine. Int. J. Greenh. Gas Control 2016, 44, 262-275. [CrossRef]

21. Dávila, G.; Luquot, L.; Soler, J.M.; Cama, J. Interaction between a fractured marl caprock and $\mathrm{CO}_{2}$-rich sulfate solution under supercritical $\mathrm{CO}_{2}$ conditions. Int. J. Greenh. Gas Control 2016, 48, 105-119. [CrossRef]

22. Jayasekara, D.W.; Ranjith, P.G.; Wanniarachchi, W.A.M.; Rathnaweera, T.D.; Van Gent, D. $\mathrm{CO}_{2}$-brine-caprock interaction: Reactivity experiments on mudstone caprock of South-west Hub geo-sequestration project. J. Pet. Sci. Eng. 2020, 189, 107011. [CrossRef]

23. Kohler, E.; Parra, T.; Vidal, O. Clayey cap-rock behavior in $\mathrm{H}_{2} \mathrm{O}-\mathrm{CO}_{2}$ media at low pressure and temperature conditions: An experimental approach. Clays Clay Miner. 2009, 57, 616-637. [CrossRef]

24. Wollenweber, J.; Alles, S.; Busch, A.; Krooss, B.M.; Stanjek, H.; Littke, R. Experimental investigation of the $\mathrm{CO}_{2}$ sealing efficiency of caprocks. Int. J. Greenh. Gas Control 2010, 4, 231-241. [CrossRef]

25. Alemu, B.L.; Aagaard, P.; Munz, I.A.; Skurtveit, E. Caprock interaction with $\mathrm{CO}_{2}$ : A laboratory study of reactivity of shale with supercritical $\mathrm{CO}_{2}$ and brine. Appl. Geochem. 2011, 26, 1975-1989. [CrossRef]

26. Rezaeyan, A.; Tabatabaei-Nejad, S.A.; Khodapanah, E.; Kamari, M. A laboratory study on capillary sealing efficiency of Iranian shale and anhydrite caprocks. Mar. Pet. Geol. 2015, 66, 817-828. [CrossRef] 
27. Wang, H.; Alvarado, V.; Smith, E.R.; Kaszuba, J.P.; Bagdonas, D.A.; McLaughlin, F.J.; Quillinan, S.A. Link between $\mathrm{CO}_{2}$-induced wettability and pore architecture alteration. Geophys. Res. Lett. 2020, 47. [CrossRef]

28. Xu, T.; Apps, J.A.; Pruess, K. Mineral sequestration of carbon dioxide in a sandstone-shale system. Chem. Geol. 2005, 217, 295-318. [CrossRef]

29. Tian, H.; Xu, T.; Zhu, H.; Yang, C.; Ding, F. Heterogeneity in mineral composition and its impact on the sealing capacity of caprock for a $\mathrm{CO}_{2}$ geological storage site. Comput. Geosci. 2019, 125, 30-42. [CrossRef]

30. Xiao, T.; Xu, H.; Moodie, N.; Esser, R.; Jia, W.; Zheng, L.; Rutqvist, J.; McPherson, B. Chemical-mechanical impacts of $\mathrm{CO}_{2}$ intrusion into heterogeneous caprock. Water Resour. Res. 2020. [CrossRef]

31. Gherardi, F.; Xu, T.; Pruess, K. Numerical modeling of self-limiting and self-enhancing caprock alteration induced by $\mathrm{CO}_{2}$ storage in a depleted gas reservoir. Chem. Geol. 2007, 244, 103-129. [CrossRef]

32. Tian, H.; Xu, T.; Li, Y.; Yang, Z.; Wang, F. Evolution of sealing efficiency for $\mathrm{CO}_{2}$ geological storage due to mineral alteration within a hydrogeologically heterogeneous caprock. Appl. Geochem. 2015, 63, 380-397. [CrossRef]

33. Dávila, G.; Cama, J.; Luquot, L.; Soler, J.M.; Ayora, C. Experimental and modeling study of the interaction between a crushed marl caprock and $\mathrm{CO}_{2}$-rich solutions under different pressure and temperature conditions. Chem. Geol. 2017, 448, 26-42. [CrossRef]

34. Xu, T.; Zhu, H.; Feng, G.; Yang, Z.; Tian, H. Numerical simulation of calcite vein formation and its impact on caprock sealing efficiency-Case study of a natural $\mathrm{CO}_{2}$ reservoir. Int. J. Greenh. Gas Control 2019, 83, 29-42. [CrossRef]

35. Ma, X.; Yang, G.; Li, X.; Yu, Y.; Dong, J. Geochemical modeling of changes in caprock permeability caused by $\mathrm{CO}_{2}$-brine-rock interactions under the diffusion mechanism. Oil Gas Sci. Technol. 2019, 74, 83. [CrossRef]

36. Xu, T.; Sonnenthal, E.; Spycher, N.; Pruess, K. TOUGHREACT-A simulation program for non-isothermal multiphase reactive geochemical transport in variably saturated geologic media: Applications to geothermal injectivity and $\mathrm{CO}_{2}$ geological sequestration. Comput. Geosci. 2006, 32, 145-165. [CrossRef]

37. Yang, G.; Li, Y.; Atrens, A.; Liu, D.; Wang, Y.; Jia, L.; Lu, Y. Reactive transport modeling of long-term $\mathrm{CO}_{2}$ sequestration mechanisms at the Shenhua CCS demonstration project, China. J. Earth Sci. 2017, 28, 457-472. [CrossRef]

38. Ma, X.; Yang, G.; Yu, Y.; Li, X.; Liu, X. Effect of clay mineral contents on sealing capacity of caprock of $\mathrm{CO}_{2}$ geological storage. Bull. Miner. Pet. Geochem. 2019, 38, 121-129. (In Chinese)

39. Xu, T.; Spycher, N.; Sonnenthal, E.; Zhang, G.; Zheng, L.; Pruess, K. TOUGHREACT Version 2.0: A simulator for subsurface reactive transport under non-isothermal multiphase flow conditions. Comput. Geosci. 2011, 37, 763-774. [CrossRef]

40. Wolery, T.J. Software Package for Geochemical Modeling of Aqueous System: Package Overview and Installation Guide (Version 8.0); Lawrence Livermore National Laboratory Report UCRL-MA-110662 PT I: Livermore, CA, USA, 1992.

41. Yang, G.; Li, Y.; Ma, X.; Dong, J. Effect of chlorite on $\mathrm{CO}_{2}$-water-rock interaction. Earth Sci. J. China Univ. Geosci. 2014, 39, 462-472. (In Chinese)

42. Wdowin, M.; Tarkowski, R.; Franus, W. Determination of changes in the reservoir and cap rocks of the Chabowo Anticline caused by $\mathrm{CO}_{2}$-brine-rock interactions. Int. J. Coal Geol. 2014, 130, 79-88. [CrossRef]

43. Charlet, L.; Alt-Epping, P.; Wersin, P.; Gilbert, B. Diffusive transport and reaction in clay rocks: A storage (nuclear waste, $\mathrm{CO}_{2}, \mathrm{H}_{2}$ ), energy (shale gas) and water quality issue. Adv. Water Resour. 2017, 106, 39-59. [CrossRef]

44. Trémosa, J.; Castillo, C.; Vong, C.Q.; Kervévan, C.; Lassin, A.; Audigane, P. Long-term assessment of geochemical reactivity of $\mathrm{CO}_{2}$ storage in highly saline aquifers: Application to Ketzin, In Salah and Snøhvit storage sites. Int. J. Greenh. Gas Control 2014, 20, 2-26. [CrossRef]

45. Lo Ré, C.; Kaszuba, J.P.; Moore, J.N.; McPherson, B.J. Fluid-rock interactions in $\mathrm{CO}_{2}$-saturated, granite-hosted geothermal systems: Implications for natural and engineered systems from geochemical experiments and models. Geochim. Cosmochim. Acta 2014, 141, 160-178. [CrossRef]

46. Sundal, A.; Hellevang, H. Using reservoir geology and petrographic observations to improve $\mathrm{CO}_{2}$ mineralization estimates: Examples from the Johansen Formation, North Sea, Norway. Minerals 2019, 9, 671. [CrossRef] 
47. Mohd Amin, S.; Weiss, D.J.; Blunt, M.J. Reactive transport modelling of geologic $\mathrm{CO}_{2}$ sequestration in saline aquifers: The influence of pure $\mathrm{CO}_{2}$ and of mixtures of $\mathrm{CO}_{2}$ with $\mathrm{CH}_{4}$ on the sealing capacity of cap rock at $37^{\circ} \mathrm{C}$ and 100 bar. Chem. Geol. 2014, 367, 39-50. [CrossRef]

48. Moore, J.; Adams, M.; Allis, R.; Lutz, S.; Rauzi, S. Mineralogical and geochemical consequences of the long-term presence of $\mathrm{CO}_{2}$ in natural reservoirs: An example from the Springerville-St. Johns Field, Arizona, and New Mexico, USA. Chem. Geol. 2005, 217, 365-385. [CrossRef]

49. Okuyama, Y.; Todaka, N.; Sasaki, M.; Ajima, S.; Akasaka, C. Reactive transport simulation study of geochemical $\mathrm{CO}_{2}$ trapping on the Tokyo Bay model-With focus on the behavior of dawsonite. Appl. Geochem. 2013, 30, 57-66. [CrossRef]

50. Tambach, T.J.; Koenen, M.; Wasch, L.J.; van Bergen, F. Geochemical evaluation of $\mathrm{CO}_{2}$ injection and containment in a depleted gas field. Int. J. Greenh. Gas Control 2015, 32, 61-80. [CrossRef]

51. Smith, M.M.; Wolery, T.J.; Carroll, S.A. Kinetics of chlorite dissolution at elevated temperatures and $\mathrm{CO}_{2}$ conditions. Chem. Geol. 2013, 347, 1-8. [CrossRef]

52. Li, Y.; Fang, Q.; Ke, Y.; Dong, J.; Yang, G.; Ma, X. Effect of high salinity on $\mathrm{CO}_{2}$ geological storage: A case study of Qianjiang Depression in Jianghan Basin. Earth Sci. J. China Univ. Geosci. 2012, 37, 283-288. (In Chinese)

53. Ranjith, P.G.; Perera, M.S.A.; Khan, E. A study of safe $\mathrm{CO}_{2}$ storage capacity in saline aquifers: A numerical study. Int. J. Energ. Res. 2013, 37, 189-199. [CrossRef]

54. Jayasekara, D.W.; Ranjith, P.G.; Wanniarachchi, W.A.M.; Rathnaweera, T.D.; Chaudhuri, A. Effect of salinity on supercritical $\mathrm{CO}_{2}$ permeability of caprock in deep saline aquifers: An experimental study. Energy 2020, 191, 116486. [CrossRef]

Publisher's Note: MDPI stays neutral with regard to jurisdictional claims in published maps and institutional affiliations. 